\title{
Towards a Measure of Financial Fragility
}

Oriol Aspachs-Bracons

Charles A.E. Goodhart

Dimitrios P. Tsomocos

Lea Zicchino

DISCUSSION PAPER 554

DISCUSSION PAPER SERIES

February 2006

Oriol Aspachs-Bracons is a PhD student in Economics at the London School of Economics and a member of the FMG. He would like to acknowledge the Fundacion Rafael Del Pino for their financial support. Charles A.E. Goodhart is Norman Sosnow Professor of Banking and Finance at the London School of Economics. He is also the Deputy Director of the Financial Markets Group Research Centre, and an advisor to the Governor at the Bank of England. Dimitrios P. Tsomocos is University Lecturer in Management Science (Finance), Said Business School and Fellow of St. Edmund Hall, University of Oxford. He is also a senior research associate at the Financial Markets Group and a consultant at the Bank of England. Lea Zicchino is an Economist at the Bank of England, Financial Industry and Regulation Division. He has a PhD in Finance and Economics (Financial structure and economic activity under asymmetric information) from Columbia Business School, New York. Any opinions expressed here are those of the authors and not necessarily those of the FMG. The research findings reported in this paper are the result of the independent research of the authors and do not necessarily reflect the views of the LSE. 


\title{
Towards a Measure of Financial Fragility*
}

\author{
Oriol Aspachs \\ Financial Markets Group, London School of Economics \\ Charles A.E. Goodhart \\ Financial Markets Group, London School of Economics \\ Dimitrios P. Tsomocos \\ St Edmund Hall and Said Business School, University of Oxford, \\ and Bank of England \\ Lea Zicchino \\ Bank of England
}

March 6, 2006

\begin{abstract}
This paper proposes a measure of financial fragility that is based on economic welfare in a general equilbrium model calibrated against UK data. The model comprises a household sector, three active heterogeneous banks, a central bank/regulator, incomplete markets, and endogenous default. We address the impact of monetary and regulatory policy, credit and capital shocks in the real and financial sectors and how the response of the economy to shocks relates to our measure of financial fragility. Finally we use panel VAR techniques to investigate the relationships between the factors that characterise financial fragility in our model, i.e. banks' probabilities of default and banks' profits to a proxy of welfare.

Keywords: Financial fragility, Banks, Regulatory policy, Monetary policy, Equilibrium analysis.
\end{abstract}

JEL classification: C33, C68, E4, E5, G11, G21.

\section{Introduction}

If everyone always paid their debts in full and at the due date, there would be little, or no, need for commercial banks. Everyone would then have the highest

\footnotetext{
${ }^{*}$ We are grateful to Thomas Belsham for contributing to the empirical analysis in this paper and to Kevin James for improvements to the code used for the simulation exercises. We also wish to thank course participants at the Centre for Central Banking Studies, Bank of England, and seminar participants at the London School of Economics for helpful comments. The views expressed are those of the authors and do not necessarily reflect those of the Bank of England.
} 
possible credit-rating, would need no monitoring, and could borrow, or lend, at the default-free rate of interest. Although many formal macro-economic models (implicitly) employ an assumption of a default-free system in their so-called transversality assumption, it is not, alas, a characteristic of the real world.

Indeed, the probability of default (PD) is a key concept in any analysis of financial fragility. It is, of course, central to the Basel II exercise. At the more formal level, modelling of default, (following on from the approach pioneered by Martin Shubik and his co-authors), is the crucial element for the analysis of financial fragility that we have been developing, see Tsomocos (2003a and b), Goodhart, Tsomocos and Sunirand (2004, 2005, 2006 a, 2006 b), Tsomocos and Zicchino (2005).

At first glance, therefore, one might think that some metric of the number and scale of defaults might, of itself, be a reasonable proxy as a metric of financial fragility. Indeed, measures of the onset, and duration, of financial crises are often based largely on major default events. Yet, for a variety of reasons we do not think that a metric of ex post bank defaults, either for individual banks or for the banking system as a whole, is quite sufficient; though surely the PD of a banking system is a key component of its fragility/stability.

Perhaps the key reason for this is that PD is not just the result of accidental events, exogenous shocks, but is in some large part determined endogenously by the risk preferences and strategies of the agents involved. Agents can consciously choose strategies which combine higher risks and higher expected profits. So if both defaults and profits rise together, it is not a sign of increased fragility, rather an indication of a shift in behavioural patterns. Similarly if the costs of bankruptcy are reduced, e.g. by legislation, one would expect a rise in defaults and failures, without that representing an indication of economic or financial weakness.

Another problem is more mundane, relating to the available data base. Major bank failures are relatively rare events, in most countries, and quite often potential failures are nipped in the bud by various forms of quasi-nationalisation and recapitalisation without their ever having been formally in default; Japan and the treatment of Credit Lyonnais are examples. So bank-level data series for defaults is difficult to use in econometric analysis. For this reason, in our empirical analysis, we use an indicator of the banking sector's probability of default.

A profitable bank is, almost by definition, not in difficulties. So, bank profitability could be a possible metric for financial fragility. But, as with PD, low profitability can be a consequence of risk aversion, that is a low profit, low risk strategy - quite common after a crisis - rather than a symptom of financial fragility itself.

This leads us towards a two variable (factor) definition of financial fragility, that is a combination of default probability and low profitability. This need for a combination of factors has some marked disadvantages. In order to provide a single metric of financial fragility, it is necessary to give some weighting to the two key variables (PD and profitability, $\pi$ ), and that can only come from numerical exercises, simulation and empirical estimation. Such exercises are inevitably illustrative rather than conclusive.

Current and expected default probabilities, and profitability, are the main fun- 
damental determinants of bank equity values. In our simulations and empirical work we examine how these factors influence bank equity valuations, and how bank equity values feed back into real output. But again we cannot use bank equity values as a single metric for financial fragility because so many other variables (factors) feed back into the determination of such values. Indeed, these interactions are so complex that we have not yet modelled such interactions in a rigorous, micro-founded, general equilibrium format; we use a reduced form simplification in the simulations.

Again in our simulations we can show how the impact of various shocks works through the system to affect bank profits, PDs and bank equity, and ultimately changes real output and real consumption. It is, of course, the latter than affects welfare. So, in our simulated system, we can define financial fragility as the relative impact of a known and given shock on output, for various prior conditions of bank, and client, capital strength, current profitability and risk preferences, for example. For our empirical analysis we will use a reduced form VAR approach to evaluate the impact of the two financial fragility "factors" (bank equity value, which we consider a proxy of bank profitability, and bank default probabilities) on output.

The plan of the rest of this paper is as follows. In Section 2 we examine alternative definitions of financial fragility. In Section 3 we provide a précis of our basic analytical model. In Section 4 we run simulations of the effect of a variety of shocks in the banking system, focussing on their impact on output via changes in PD, banks' profits and banks' equity values on output. Then in Section 5 we explore the effects of shocks to bank equity values and bank probabilities of default on output using a panel-VAR approach. Section 6 concludes and indicates directions for future work.

\section{Alternative definitions of financial fragility?}

Numerous other authors have tackled financial stability and at one level the term seems to be familiar both from a theoretical as well as a practical viewpoint. However, few attempts have been made to define and formally characterise it in an analytically rigorous way. Academics and policy-makers have offered various definitions. ${ }^{1}$ For example, Andrew Crockett (1997) argues that 'financial stability (refers) to the stability of the key institutions and markets that go to make up the financial system... stability requires (i) that the key institutions in the financial system are stable, in that there is a high degree of confidence that they continue to meet their contractual obligations without interruption or outside assistance; and (ii) that the key markets are stable, in that participants can confidently transact in them at prices that reflect fundamental forces and that do not vary substantially over short periods when there have been no changes in fundamentals'. Mishkin (1994) offers a more 'information-based' definition. 'Financial instability occurs when shocks to the financial system interfere with information flows so that the financial system can no longer do its job of channelling funds to those with productive investment opportunities'.

\footnotetext{
${ }^{1}$ A survey of these definitions and extensive discussion can be found in Bank for International Settlements (1998).
} 
Other authors have emphasised deviations from the optimal investment/savings plan as a necessary ingredient of a definition of financial instability. For example, Haldane et al (2004) propose the following definition: '...financial instability could be defined as any deviation from the optimal saving-investment plan of the economy that is due to imperfections in the financial sector.' However, as Otmar Issing has pointed out, '...the efficient allocation of savings to investment, though without doubt a highly desirable feature of an economy, should not be part of a definition of financial stability. For example, no-one would say that savings were allocated efficiently to investment opportunities in the Soviet Union between 1917 and 1991, but the Soviet Union did not suffer from financial instability, except right at the end of its existence.'2

Issing (2003) and Foot (2003) have suggested that financial stability is related to financial market bubbles, or more generally, volatility in financial market proxies. Indeed, bubbles impair financial markets efficiency, however, in and of themselves, they do not constitute a defining characteristic of financial fragility, and more generally financial instability. One can classify Minsky's Financial Instability Hypothesis in this family of definitions ${ }^{3}$ since he claims that the inherent financial instability of financial markets is based on the overoptimistic behaviour of economic agents. Finally, Anna Schwartz (1986) suggests that 'a financial crisis is fuelled by fears that means of payment will be unobtainable at any price and, in a fractional reserve banking system, leads to a scramble for high powered money... In a futile attempt to restore reserves, the banks may call in loans, refuse to roll over existing loans, or resort to selling assets.' Allen and Wood (2005) offer a related definition.

The definition of financial fragility that we are proposing, for the reasons already set out, is: ${ }^{4}$

A combination of probability of default (PD) - variously measured together with bank profitability. This has the added advantage that he can be applied, mutatis mutandis, at both the individual and aggregate levels.

Thus, financial instability is characterised by both high PDs and low profits. Moreover, the authorities (government and/or the Central Bank) can influence the level of debt above which (and the profit below which), a financial environment becomes fragile. Also note that this definition can be related to the welfare of the economy and its distributional consequences. This in turn conforms with deviations from the optimal savings and investment plan in equilibrium, as has been suggested by Haldane et al (2004). The standard techniques and theorems of equilibrium theory can be readily applied. Equilibrium analysis is also amenable to comparative statics, for example, by varying capital requirement rules one can affect default probabilities and the welfare effects of a crisis.

This definition is sufficiently flexible to encompass most of the recent episodes of financial instability. The Mexican crisis of the early 1990s is a classic example of such a crisis. The late 1990s east Asian crisis was characterised by a banking crisis

\footnotetext{
${ }^{2}$ From Issing (2003).

${ }^{3}$ See Minsky (1985)

${ }^{4}$ See Goodhart C.A.E., P, Sunirand, and D.P. Tsomocos (2004), and Tsomocos (2003 a,b) for a formal definition.
} 
and economic recession as well as extensive default. Finally, the Russian crisis, the Texas Banking crisis, and the U.S. Stock Market crash of 1987 conformed to the characterisation of a financially unstable regime generated by extensive default and declines in bank profitability.

In summary, the information-based definition of Mishkin, and of Issing and Foot, and the institutionally oriented one offered by Crockett and Schwarz encompass crucial aspects of financial instability; however, they do not capture the main reason that policy-makers focus on instability, namely its welfare and distributional effects. In other words, their definitions highlight the inefficiency that a financially unstable regime generates but they are too general to be applicable for policy analysis. Widespread default and a pronounced decrease in banks profitability eventually impair markets and eventually trade collapses altogether. Thus, a systemic financial crisis of the economy can be reinterpreted as a case of equilibrium non-existence.

We now provide a brief description of the model on which our analysis is based. ${ }^{5}$

\section{Description of the model}

The model incorporates heterogeneous banks and capital requirements in a general equilibrium model with incomplete markets, money and default. It extends over two periods and all uncertainty is resolved in the second period. Trade takes place in both periods in the goods and equity markets. In the first period agents also borrow from, or deposit money with banks, mainly to achieve a preferred time path for consumption. Banks also trade amongst themselves, to smooth out their individual portfolio positions. The Central Bank intervenes in the interbank market to change the money supply and thereby set the interest rate. Capital adequacy requirements (CARs) on banks are set by a regulator, who may, or may not, also be the Central Bank. Penalties on violations of CARs, and on the default of any borrower, are in force in both periods. In order to achieve formal completeness for the model, banks are liquidated at the end of the second period and their profits and assets distributed to shareholders. Figure 2 makes the time line of the model explicit.

\footnotetext{
${ }^{5}$ For an extensive description of this variant of the model see Appendix I and Goodhart et al (2005)
} 


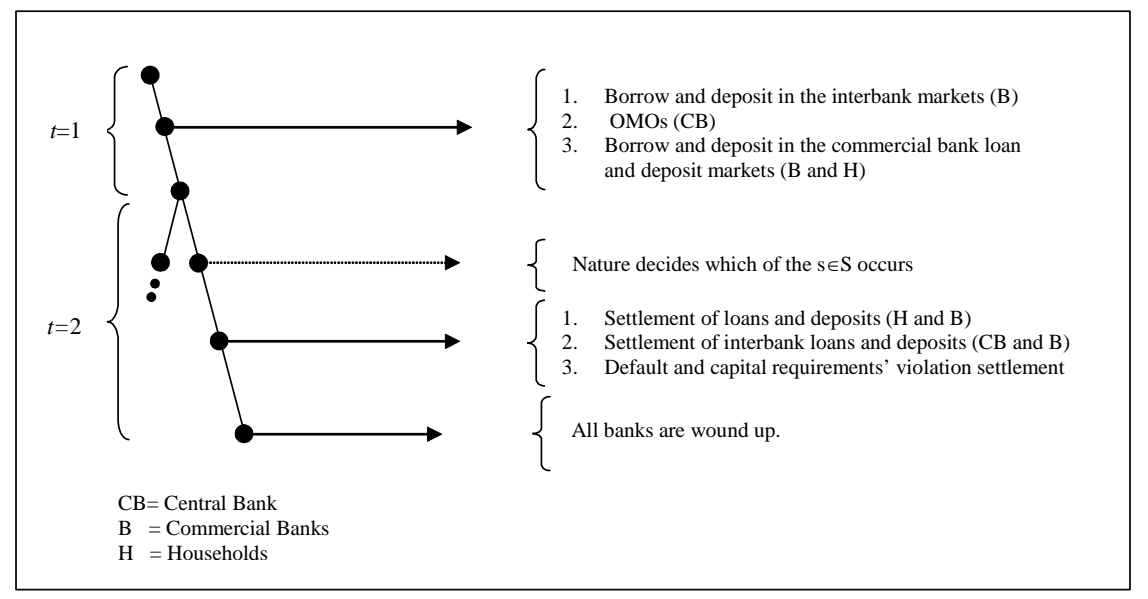

Figure 1: The time structure of the model

In the first period trades by all agents take place against a background of uncertainty about the economic conditions (the state of nature) that will prevail in the second period. Agents are, however, assumed to have rational expectations, and to know the likelihood (the probability distribution) of good or bad states occurring when they make their choices in period one. In period two the actual economic conjuncture (the state of nature) is revealed and all uncertainty is resolved.

The model incorporates a number of distinct, i.e. heterogeneous, commercial banks, each characterised by a unique risk/return preference and different initial capital. Since each bank is, and is perceived as being, different, it follows that there is not a single market for either bank loans or bank deposits. In addition, we introduce limited access to consumer credit markets, with each household assigned (by history and custom) to borrow from a predetermined bank. This feature allows for different interest rates across the commercial banking sector. In sum, multiple credit and deposit markets lead to different loan rates among various banks and to endogenous credit spreads between loan and deposit rates.

Individual non-bank agents are also assumed to differ in their risk attitudes and hence in their preferences for default. We model the incentive for avoiding default by penalising agents and banks proportionately to the size of default. Banks that violate their capital adequacy constraint are also penalised in proportion to the shortfall of capital. Both banks and households are allowed to default on their financial obligations, but not on commodity deliveries.

Our specification of the banking sector is based on a system comprising the seven largest UK banks: Lloyds, HSBC, Abbey National, HBOS, Barclays, Royal Bank of Scotland, and Standard Chartered; though the same modelling approach could, in principle, be applied to the banking system of any other country, or region. Banks $\gamma$ and $\delta$ can represent any two of these individual banks, whereas bank $\tau$ represents the aggregation of the remaining banks. In our calibration exercises, banks $\gamma$ and $\delta$ will be chosen specifically to represent two of these actual UK banks. However, for data confidentiality reason, we will not reveal their identities. 
All banks in the model, $b \in B=\{\gamma, \delta, \tau\}$, are assumed to operate under a perfectly competitive environment (i.e. they take all interest rates as exogenously given when making their optimal portfolio decisions). The structure of their balance sheets is given below;

\begin{tabular}{|l|l|}
\hline Assets & Liabilities \\
\hline Loans to agents & Deposits from Mr. $\phi$ \\
Interbank deposits & Interbank borrowing \\
Market book & Equity \\
& Others \\
\hline
\end{tabular}

We assume that all banks endogenise their decisions in the loan, deposit and interbank markets. ${ }^{6}$ The remaining variables are treated as exogenous. ${ }^{7}$ We further assume that banks can default on their financial obligations, subject to default penalties set by the regulator. Thus, by varying the penalties imposed on default from 0 to infinity, we can model $100 \%$ default, no default or an equilibrium level of default between 0 and $100 \% .{ }^{8}$ At first sight, this 'continuous' default rate approach may seem problematic since in reality banks either repay in full at the due date or are forced to close down. However, we interpret a bank's default rate in our model as a probability that such bank chooses to shut down, and hence in the short run to default completely on its financial obligations. Therefore, a bank's decision to increase its default rates is isomorphic to its decision to adopt a riskier position in pursuit of higher expected profitability. ${ }^{9}$ With a large number of agents, as in a competitive equilibrium, conditions where everyone defaults on, say, $5 \%$ of their liabilities are equivalent to those where $5 \%$ of agents default on all their debts. This, however, is not the case when there are only a few agents in a concentrated field. If there are, say, only two agents in the field, and their failures are independent of each other, then in $0.25 \%$ of all cases there will be $100 \%$ default, in $9.75 \%$ of cases $50 \%$ default, and in $90 \%$ of cases no default, which is clearly vastly different from a $5 \%$ default rate amongst a large number of agents.

In most countries banking is a concentrated service industry. Moreover, reputational effects and cross-default clauses, amongst other things, mean that banks cannot default partially and remain open. If they cannot meet their payment obligations, (except under force majeure as in 9/11), they have to close their doors. Except when such closed banks are tiny, such closure does not however, in almost all cases, then turn into permanent liquidation. Effectively almost all banks are restructured, often via a 'bridge bank' arrangement, and shortly re-open, with the extent of short-fall of assets distributed amongst the various creditors, (the 'haircut' in the American phrase), the shareholders and taxpayers depending on the deposit

\footnotetext{
${ }^{6}$ The modelling of the banking sector follows Shubik and Tsomocos (1992) and Tsomocos (2003a and $\mathrm{b})$.

${ }^{7}$ As explained in Goodhart et al. (2005), we cannot endogenise banks' decisions on market book or equity. Since the model has two states in the second period and one unconstrained asset, the interbank market investment, adding another unconstrained asset would make the markets complete.

${ }^{8}$ This modelling of default follows Shubik and Wilson (1977).

${ }^{9}$ For more on this issue, see work in progress by Tsomocos and Zicchino (2004).
} 
insurance arrangements, bank bankruptcy laws and political pressures. In this latter sense, even though the banking system is concentrated, and banks have to close when they cannot meet due payments, it is perfectly valid to assess strategies as bringing about possible conditions in which a bank defaults by, say, $5 \%$ to all depositors, because that would be the effective loss of funds, or haircut, in the event of a bad state of the world.

Finally, as in Bhattacharya et al. (2003), we make a simplifying assumption by assuming that banks' default rates in the deposit and interbank markets are the same, i.e. that banks are restricted to repay all their creditors in the same proportion.

Banks can also violate their capital adequacy requirement, subject to capital requirement violation penalties set by the regulator. In principle, each bank's effective capital to asset ratios may not be binding, (i.e. their values may be above the regulator's requirement), in which case they are not subject to any capital requirement penalty. However, in our calibration exercises, we assume for simplicity that each bank wants to keep a buffer above the required minimum, so that there is a non-pecuniary loss of reputation as capital declines; in this sense the ratios are always binding. Put differently, we assume that banks' self-imposed ideal capital holdings are always above the actual values of all banks' capital to asset ratios. Given this assumption, we can rule out corner equilibria and therefore focus our analysis entirely on well-defined interior solutions whereby banks violate their enhanced capital requirements. We assume that penalties are linear as capital declines from its ideal level. ${ }^{10}$

The calibration exercises presented in sections 4 are based on the data of UK banks at the end of 2002. At that point in time, bank $\delta$ is a net lender whereas banks $\gamma$ and $\tau$ are net borrowers in the interbank market. ${ }^{11}$ The optimisation problem of banks, as well as the rest of the model, is described in more detail in Appendix I. ${ }^{12}$

\section{Comparative statics analysis}

We now turn to a description of the outcome of the exercise where we sought to calibrate the model against UK data. As noted earlier, the model has two periods, and in our simulation exercises, two possible states in the second period, with state 1 being the 'good' state, and 2 the 'bad' state. There are four households, denoted with $\alpha, \beta, \theta$ and $\phi$, three banks, $\delta, \gamma$ and $\tau$ and a central bank/regulator. Given the limited participation condition in the loan market, households $\alpha, \beta$, and $\theta$ borrow from banks $\gamma, \delta$, and $\tau$, respectively. Household $\phi$ represents a pool of depositors who are able to deposit with any of the banks. We do not in fact know the identities, nor do

\footnotetext{
${ }^{10}$ In practice, there will be some non-linearity as capital falls below its required minimum, but this is just too complex to model at this stage.

${ }^{11}$ As noted earlier, we have chosen banks $\gamma$ and $\delta$ to represent specifically two of the seven largest UK banks in our calibration exercise. Bank $\tau$ then represents the aggregation of the remaining five banks.

${ }^{12}$ The interested reader can also refer to Goodhart et al (2005). The model used here has a slightly different specification of the reduced-form equations describing the behaviour of the household sector.
} 
we have data available for, these sets of borrowers who borrow from each individual bank, i.e. there is a lack of data for households disaggregated by their connection to particular banks. Owing to this lack of such data, we model the behaviour of the various households via reduced-form equations. ${ }^{13}$ Finally, the Central Bank uses its ability to vary the monetary base as its monetary policy instrument and fixes the supply of bank reserves by injecting, or withdrawing, funds in the interbank market. There is, of course, a dual relationship between the policy-determined short-term interest rate and the quantity of bank reserves, though this relationship can be affected by the institutional details of the precise way in which the Central Bank operates in the money markets. In practice, Central Banks always set interest rates rather than the reserve base (see Bindseil, 2004). One reason that they do so is that setting interest rates (rather than reserve quantities) strongly dampens the effects of certain shocks on the banking system. But by the same token, taking the reserve base as fixed in our simulations provides clearer and stronger responses to shocks, which is useful for illustrative purposes. Meanwhile, the regulator sets the capital adequacy requirements, and also the penalties for infringing these. At the same time, the penalties for default are quite largely non-pecuniary, depending on reputational loss, the severity of the bankruptcy laws in limiting future options, etc. Again, we do not attempt to model these, at any rate at this stage, with any great accuracy, and therefore we treat them as predetermined.

As it will become clear from the following comparative statics exercises, whenever a shock to the economy induces financial fragility, GDP (which we take as a proxy of welfare) decreases. ${ }^{14}$

\subsection{A contractionary monetary policy shock}

We report the results of simulated shocks to the economy under the assumption that banks are constrained by a capital requirement. We then repeat the simulations under the assumption that CARs are not in place. In the next two sections we report and explain the reaction of key variables to a tightening of monetary policy (under the assumption that the Central Bank uses its base money as its monetary policy instrument). The results of additional comparative statics exercises are presented in Appendix II. ${ }^{15}$

\subsubsection{Case I: banks are subject to a capital adequacy requirement}

The percentage changes in the values of the variables in response to a 10 percent drop in the Bank's base money (from 69.28 to 62.30 trillion pounds) are shown in Table 1.

\footnotetext{
${ }^{13}$ See equations (12)-(15) in Appendix I

${ }^{14}$ In the more general set-up of the model, where household choices are derived from agents maximising their utility functions, financial fragility is always associated to a decrease in the sum of agents' utility.

${ }^{15}$ See also Goodhart and Zicchino (2005) for a description of analogous simulation exercises.
} 


\begin{tabular}{|c|c|c|c|c|c|c|c|c|c|c|c|c|c|}
\hline & Inte & rest $r$ & ates & & & & & & & & & & \\
\hline & $r_{d}^{b}$ & $r^{b}$ & $\rho$ & $\pi_{i}^{\nu}$ & $\pi_{i i}^{i}$ & $e_{i}^{U}$ & $e_{i i}^{U}$ & $k_{i}^{D}$ & $k_{i i}^{D}$ & $v_{i}^{U}$ & $v_{i i}^{U}$ & $G D P_{i}$ & $G D P_{i i}$ \\
\hline Bank $\delta$ & 2.8 & 3 & \multirow{3}{*}{2.4} & 0.06 & 0.1 & 0.005 & 0.003 & 0.35 & 0.38 & -0.02 & -0.04 & \multirow{3}{*}{-0.18} & \multirow{3}{*}{-0.17} \\
\hline Bank $\gamma$ & 2.4 & 3.3 & & 0.12 & 0.3 & 0.03 & 0.08 & 0.5 & 0.6 & 0.005 & -0.04 & & \\
\hline Bank $\tau$ & 2.4 & 3.3 & & 0.02 & 0.03 & 0.005 & 0.005 & 0.47 & 0.5 & 0.003 & -0.01 & & \\
\hline
\end{tabular}

Legend:

$r^{b}=$ lending rate offered by bank $b \in B=\{\delta, \gamma, \tau\}$,

$r_{d}^{b}=$ deposit rate offered by bank $b$,

$\rho=$ interbank rate,

$\pi_{s}^{b}=$ profits of bank $b$ in state of the world $s=\{i, i i\}$,

$e_{s}^{b}=$ capital held by bank $b$ in state $s$,

$k_{s}^{b}=$ ratio of capital to risk-weighted assets of bank $b$ in state $s$,

$v_{s}^{b}=$ repayment rate of bank $b$ to all its creditors in state $s$,

$G D P_{s}=$ GDP in state $s$.

As can be seen from the table, the interbank rate increases by 2.4 percent (from $4.41 \%$ to $4.52 \%$ ). Given a higher rate of return on interbank loans, other things equal, bank $\delta$ invests more in this market. To do so, it seeks more funds from the deposit markets and it cuts on lending to its customer, $\beta$ (banks' loans are not shown in Table 1). ${ }^{16}$ This portfolio adjustment causes a $2.8 \%$ increase in $\delta$ 's deposit rate and a $3 \%$ increase in its lending rate (from 3.88\% to $3.99 \%$ and from $7.45 \%$ to $7.68 \%$, respectively). Banks $\gamma$ and $\tau$, who are net borrowers in the interbank market, respond to a higher $\rho$ by reducing their interbank borrowing, by increasing their demand for deposits, and by reducing loan supply to their customers, $\alpha$ and $\theta$. This, in turn, causes the deposit and lending rates of these to banks to increase.

All banks anticipate that a lower credit availability will cause a higher rate of households' default as the decrease in liquidity affects next-period income negatively (GDP decreases in both states of the world). Households' repayment rates decrease by approximately $0.1 \%$ in the good state of the world and by 0.14 percent in the bad state (not shown in Table 1). Thus, the expected rate of return on loans decreases for all banks and their willingness to supply credit decreases even further. The lower rate of return on household loans and the higher cost of funds have a negative effect on the profits of banks $\gamma$ and $\tau$ while bank $\delta$ benefits from the higher return on interbank market investments. However, since banks are subject to a capital requirement and therefore need to increase their profits to accumulate capital, they choose to increase their default rates (the default rates increase when the repayment rates $v_{s}^{b}$ decrease). Put in another way, banks adopt riskier strategies to counteract the negative effect on profits of the liquidity contraction.

\footnotetext{
${ }^{16}$ The complete comparative statics results are available on request.
} 


\subsubsection{Case II: banks are not subject to capital requirements}

We perform the same comparative statics exercises under the assumption that banks do not have to comply with a capital adequacy requirement. We present here the results of a contractionary monetary policy and report the rest of the simulations in Appendix II. This additional set of simulations allows us to better assess the role of capital adequacy regulation in the transmission of shocks to the banking system and to the economy.

We assume a tightening of monetary policy under the assumption that the Central Bank uses changes in base money as its monetary policy instrument.

The percentage changes in the values of the variables in response to a $10 \%$ drop in the Bank's base money (from 69.28 to 62.30 trillion pounds) are shown in Table 2 .

\begin{tabular}{|c|c|c|c|c|c|c|c|c|c|c|c|c|c|}
\hline & \multicolumn{3}{|c|}{ Interest rates } & \multirow{2}{*}{$\pi_{i}^{b}$} & \multirow{2}{*}{$\pi_{i i}^{b}$} & \multirow{2}{*}{$e_{i}^{b}$} & \multirow{2}{*}{$e_{i i}^{b}$} & \multirow{2}{*}{$k_{i}^{b}$} & \multirow{2}{*}{$k_{i i}^{b}$} & \multirow{2}{*}{$v_{i}^{b}$} & \multirow{2}{*}{$v_{i i}^{b}$} & \multirow[b]{2}{*}{$G D P_{i}$} & \multirow[b]{2}{*}{$G D P_{i i}$} \\
\hline & $r_{d}^{b}$ & $r^{b}$ & $\rho$ & & & & & & & & & & \\
\hline Bank $\delta$ & 3.1 & 3.3 & \multirow{3}{*}{2.7} & 0 & 0.003 & 0 & 0 & 0.35 & 0.38 & -0.02 & -0.04 & \multirow{3}{*}{-0.18} & \multirow{3}{*}{-0.18} \\
\hline Bank $\gamma$ & 2.7 & 3.7 & & 0.005 & 0.004 & 0.001 & 0.002 & 0.5 & 0.6 & 0.007 & -0.008 & & \\
\hline Bank $\tau$ & 2.7 & 3.6 & & -0 & -0 & -0 & -0 & 0.5 & 0.5 & 0.004 & -0.01 & & \\
\hline
\end{tabular}

Qualitatively the results are very similar to the ones obtained in the previous exercises. A key difference however is that the change in bank profitability is now smaller (and for one bank it is slightly negative). This is due to the fact that banks have now a lower incentive to raise capital, and therefore profits. Furthermore, the lower value of bank equity (not shown in the table) has the effect that GDP falls slightly more with respect to the analogous simulation with CARs.

\subsection{Do capital requirements affect financial fragility?}

For a variety of reasons the Modigliani-Miller theorem, whereby the liability structure of a firm is immaterial to its overall valuation, is inapplicable to banks. These reasons include incomplete markets, dead-weight bankruptcy costs, the existence of tax shelters, etc. There is, therefore, an internal equilibrium wherein a bank will choose a preferred distribution of equity (type) capital and (fixed interest) deposit liabilities.

Owing to the risk of contagion, whereby, through a variety of routes, e.g. defaults on interbank liabilities, forced asset sales depressing asset values, etc., failure in one bank can generate failures in other banks, more capital in bank $i$ can also help to protect depositors in bank $j$ (allowing bank $i$ to survive larger shocks). But this (social) benefit will not be internalised. Hence the argument that social benefits 
will be enhanced by requiring banks to hold more capital than they would otherwise have done.

The stylised fact is that, at the bank's individually chosen equilibrium, the mean expected return to equity is greater than the interest rate payable on deposits. Hence an effective CAR, i.e. one that actually does raise capital ratios, will mean that, if the prior equilibrium asset portfolio was maintained, profits will now fall below their desired level. So a bank will now choose higher profitability, ceteris paribus, but can only do this by taking on more risk (in an efficient market) and/or by raising interest rate spreads. In turn, such higher interest rates, charged to borrowers, will cause them to borrow less, which (in our model) reduces GDP and to take on riskier projects (i.e. to plan to default more often).

So, the benefits to financial stability of safer banks (o.a. higher capital and higher overall profits) will be offset, to some extent, by both banks and bank borrowers selecting riskier portfolios (choosing to accept higher probabilities of default), higher interest rates and lower output. This is, indeed, the pattern that appears in our simulations. In all cases, except one, profitability is higher following an adverse shock when an effective CAR is in place. The exception is in the bad state after an increase in default penalties. This is intuitive since CARs cause banks to choose higher default probabilities, so an increase in such penalties will induce them to reverse their tracks, at least partially.

In our simulations, and model, the imposition of CARs leads banks to raise interest rate spreads (marginally), and hence lead to slightly lower bank borrowing, and hence GDP. Again the simulations show a slightly greater decline in GDP, when an adverse shock occurs, when CARs are in place, with, as before, an exception when the shock is an increase in default penalties.

What this tells us is that CARs will influence bank/borrowers' behaviour towards the adoption of greater risk and charging higher rates. This is well known in the academic literature (Hellman et al. (2000), Repullo (2004), Repullo and Suarez (2004)). Even if this offset to CARs were unchecked, their introduction might still be a net benefit, depending on the likelihood of bank contagion, the expected form and probability of future shocks, etc.

In practice this adverse side-effect can be mitigated by relating CARs more closely (than we have modelled here) to the relative riskiness of assets (as done in Basel II), by raising default penalties (to counter the incentive to choose riskier strategies), or by limiting the allowable rise in interest rates (as suggested by Hellman et al; this latter has various unfortunate side effects).

Could one use this kind of model to try to estimate those values of CAR and default penalties that would maximise social welfare? In principle the answer is yes, but in practice the range on inherent uncertainties (e.g. on future shocks), the necessity for heroic assumptions and simplifications, etc., would make any such attempt an illustrative exercise rather than a practical tool kit, at least for the time being. 


\section{Empirical Analysis}

In the following sections we analyse the relationship between a small number of macroeconomic variables and both the probability of default and equity index of the banking sector of seven industrialised countries. The upshot of our econometric analysis is to examine the impact of bank default and profitability on GDP in order to asses the definition of financial stabilty discussed in section 2 .

\subsection{Data, variables and stylised facts}

Data were collected for countries, some of which had experienced episodes of financial stress, and for which a measure of the probability of default of the banking sector was available. These countries are: Finland, Norway, Sweden, Korea, UK, Germany, and Japan. The sample period is from the fourth quarter of 1990 to the fourth quarter of 2004.

The tests sought to examine whether financial fragility, defined as either, or both of, an increase in $\mathrm{PD}$ rates and a reduction in profitability, would have an impact upon economic welfare. The macroeconomic variables were obtained from the IMF's International Financial Statistics and the OECD. Inflation is defined as growth rate in the CPI index and the interest rate is the IFS call money rate. Residential property prices were obtained from the BIS. For each country, an index of banking sector equity, obtained from Bloomberg, was used to proxy banking sector profitability. The measure of the probability of default of the countries' banking sectors is a transformation of the distance to default indicator (DD) used by the IMF to gauge banking sector soundness. ${ }^{17}$

On the basis of simple statistics, as expected a priori, for most of the countries in the sample there appears to be a negative correlation between defaults and profitability.

\subsection{Econometric model and regression results}

We use a panel data Vector Autoregression (panel VAR) methodology for our empirical investigation. ${ }^{18}$ This technique combines the traditional VAR approach, which treats all the variables in the system as endogenous, with the panel data approach, which allows for unobserved heterogeneity. We specify our model of order $s$ as follows:

$$
z_{i, t}=\Gamma_{0}+\Gamma_{1} z_{i, t-1}+\Gamma_{2} z_{i, t-2}+\ldots+\Gamma_{s} z_{i, t-s}+f_{i}+e_{t}
$$

In our main model $z_{i, t}$ represents a four-variable vector $\{p o d, g d p, e q$, inf $\}$, where pod, a transformation of the distance to default, is our measure of the banking sector's default risk, $g d p$ is the growth rate of GDP, $e q$ is the annual growth rate of the bank equity index , and inf is the inflation rate. In all models, the variable pod is further transformed so that it has a value greater than zero only in those quarters in which it is above a given threshold, otherwise it is set equal to zero. Earlier

\footnotetext{
${ }^{17}$ See Goodhart, Hofmann and Segoviano (2005) for more details on how the measure is constructed.

${ }^{18}$ The analysis has been conducting using the programme developed by Love (2001).
} 
testing had shown that pod had a non-linear relationship with GDP. Below a certain threshold, whose value was estimated by empirical examination, fluctuations in pod had no effect on GDP. Similarly, fluctuations in bank equity values also appear to have a threshold effect on GDP, with the threshold also empirically estimated. It is only when bank equity declines, fairly sharply, that GDP is adversely affected.

We focus on the impulse-response functions, which describe the reaction of one variable to the innovations in another variable in the system, while holding all other shocks equal to zero. However, since the actual variance-covariance matrix of the errors is unlikely to be diagonal, to isolate shocks to one of the variables in the system, it is necessary to decompose the residuals in such a way that they become orthogonal. We do this by applying a Choleski decomposition of the variancecovariance matrix of the residuals (this is equivalent to transforming the system in a recursive VAR). The identifying assumption is that the variables that come earlier in the ordering affect the following variables contemporaneously, as well as with lags, while the variables that come later affect the previous variables only with lags. In our specifications we assume that the probability of default affects all other variables in the system contemporaneously and with lags, while macroeconomic variables such as GDP and inflation affect the default risk of the banking sector only with a lag. We experimented with different ordering of the variables (and therefore different identification assumptions) and obtained results that were qualitatively similar to the ones presented here. In applying the VAR procedure to panel data, we need to impose the restriction that the underlying structure is the same for each crosssectional unit. Since the constraint is likely to be violated in practice, one way to overcome the restriction on the parameters is to allow for individual heterogeneity in the levels of the variables by introducing fixed effects, denoted by $f_{i}$ in equation (1). Since the fixed effects are correlated with the regressors due to lags of the dependent variables, the mean-differencing procedure commonly used to eliminate fixed effects would create biased coefficients. To avoid this problem we use forward mean-differencing, also referred to as the 'Helmert procedure' (See Arellano and Bond, 1995). This procedure removes only the forward mean, i.e. the mean of all the future observations available for each country-quarter. This transformation preserves the orthogonality between transformed variables and lagged regressors, so we can use lagged regressors as instruments and estimate the coefficients by system GMM.

In the simulations based on the calibrated model we show that whenever banks' default rates increase and banks' profitability decrease (above the threshold), i.e. when the economy is more financially fragile, GDP (our proxy of welfare) falls. ${ }^{19}$ For this reason we claim that the two 'banking sector' variables are a measure of the financial instability of an economy. Our aim here is to investigate whether data give any support to our model, namely that our two measures of banking sector's distress do have the predicted impact on output. We thus proceed by analysing

\footnotetext{
${ }^{19}$ In the general version of the model, an increase in default and a decrease in profitability is always associated with a reduction in agents' welfare (see Goodhart, Sunirand and Tsomocos (2004)
} 
the impulse response functions of the VAR model. Estimate of these and their confidence intervals are shown in Figures 2-4 in Appendix III. ${ }^{20}$

Figure 2reports the impulse-responses for a 3 lag VAR including pod, gdp, eq, and inf. The second row in the figure shows the response of $g d p$ to a one standard deviation shock to the other variables of the model. The response of GDP growth to pod is negative and significant (i.e. an increase of the default probability of the banking sector induces a decrease in the growth rate of GDP). Also, the response of GDP growth to a shock to the banking sector equity index is positive and significant. Put in a different way, maintaining all other variables constant, a positive shock to the banks' probability of default has a negative impact on output while a positive shock to the banks' equity value has a positive impact on output. These results are in line with the predictions of our model. The rest of the impulse response estimates are quite standard and intuitive: the bank equity index responds negatively to a positive shock to the bank probability of default while the impact of GDP growth on the same index is positive but marginally significant. Finally, a positive innovation in output growth induces a negative and significant decrease in inflation. This would be consistent with a positive supply shock. However, we do not estimate a structural model, so we are not able to identify supply and demand factors.

In order to check the robustness of the results, we run additional regressions adding a few variables that are usually included in small macroeconomic models for the analysis of monetary transmission and monetary policy (see for example Goodhart and Hofmann, 2005). Figure 3 reports the impulse-responses of a 3 lag VAR where a property price index, propprice, is added to the variables of the previous specification. The first row shows the responses of pod: its response to a positive shock to property prices is negative and significant. This is likely due to the fact that a higher property price index translates in a higher bank asset values, which in turn decreases banks' probability of default. As the second row in Figure 3 shows, the impact of a shock to pod of $g d p$ is less significant that in the previous specification but it still goes in the right direction.. Moreover, $g d p$ responds positively to a shock to the property price index. The response of the bank equity index to a shock to bank default risk is less marked than before but still negative while the response to a positive output shock is more significant and more persistent.

Finally, we analyse a model that includes the short term interest rate, $i r$. Figure 4 shows the impulse-responses. Their behaviour is very similar to the previous model. The impact of the added variable, the short term interest rate, is quite intuitive. A positive shock to ir induces a positive response of the banking sector's probability of default, a negative response of GDP growth, a negative response of

\footnotetext{
${ }^{20}$ We calculate standard errors of the impulse-response functions and generate confidence intervals with Monte Carlo simulations. In practice, we randomly generate a draw of the coefficients $\Gamma$ in model (1) using the estimated coefficients and their variance-covariance matrix and recalculate the impulse-responses. We repeat this procedure 1000 times (we experimented with a larger number of repetitions and obtained similar results). We generate the 5 th and 95 th percentiles of this distribution, which we use as a confidence interval for the impulse-responses.
} 
property prices. The response of inflation is however positive. This result is common to most of the VAR estimations of small macroeconomic models and can often be removed by adding another variable measuring import or commodity prices.

\subsection{Variance decomposition}

The variance decomposition of the models confirm the main results. Although, as expected, the variation in GDP growth 10 and 20 quarters ahead is mainly explained by GDP growth itself, bank probability of default and equity index explain a significant part of its change in the basic model specification (see Table 9).

\begin{tabular}{|c|c|c|c|c|c|}
\hline Model (1) & $\begin{array}{c}\text { Quarters } \\
\text { ahead }\end{array}$ & pod & $g d p$ & equity & inf \\
\hline \multirow{2}{*}{ pod } & 10 & 97.32 & 0.87 & 1.45 & 0.35 \\
\hline & 20 & 97.18 & 0.96 & 1.48 & 0.36 \\
\hline \multirow{2}{*}{$g d p$} & 10 & 11.12 & 86.38 & 2.09 & 0.38 \\
\hline & 20 & 11.28 & 86.13 & 0.27 & 0.4 \\
\hline \multirow{2}{*}{ equity } & 10 & 41.19 & 6.09 & 50.77 & 1.63 \\
\hline & 20 & 41.27 & 6.39 & 50.63 & 1.69 \\
\hline \multirow{2}{*}{ inf } & 10 & 16.19 & 10.71 & 10.11 & 62.97 \\
\hline & 20 & 16.42 & 10.87 & 11.02 & 61.68 \\
\hline
\end{tabular}

When we include a property price index in the regression, this variable explains variation in gdp more than bank equity values, as shown in Table 10.

Table 10: Variance-decompositions: percent of variation in the row variable explained by column variable

\begin{tabular}{|c|c|c|c|c|c|c|}
\hline Model (2) & $\begin{array}{c}\text { Quarters } \\
\text { ahead }\end{array}$ & pod & $g d p$ & equity & inf & propprice \\
\hline \multirow{2}{*}{ pod } & 10 & 63.40 & 8.59 & 1.35 & 3.30 & 23.35 \\
\hline & 20 & 62.96 & 8.57 & 1.42 & 3.85 & 23.19 \\
\hline \multirow{2}{*}{$g d p$} & 10 & 7.36 & 85.44 & 0.48 & 1.78 & 4.92 \\
\hline & 20 & 7.56 & 84.12 & 0.57 & 2.35 & 5.38 \\
\hline \multirow{2}{*}{ equity } & 10 & 16.16 & 16.00 & 58.94 & 5.17 & 3.70 \\
\hline & 20 & 16.12 & 15.79 & 58.67 & 5.30 & 4.10 \\
\hline \multirow{2}{*}{ inf } & 10 & 6.60 & 3.90 & 1.20 & 87.96 & 0.32 \\
\hline & 20 & 6.81 & 4.31 & 1.48 & 86.67 & 0.71 \\
\hline \multirow{2}{*}{ propprice } & 10 & 10.96 & 10.73 & 15.99 & 20.46 & 41.84 \\
\hline & 20 & 12.04 & 10.77 & 19.41 & 21.12 & 36.63 \\
\hline
\end{tabular}


Finally, adding the short term interest rate to variable does not seem to alter the result of the previous specification: the bank equity index does not have much explanatory power of the variation in $g d p$ (see Table 11).

Table 11: Variance-decompositions: percent of variation in the row variable explained by column variable

\begin{tabular}{l|ccccccc}
\hline \hline Model (3) & $\begin{array}{l}\text { Quarters } \\
\text { ahead }\end{array}$ & pod & gdp & equity & inf & ir & propprice \\
\hline pod & 10 & 57.57 & 10.81 & 1.68 & 1.37 & 5.08 & 23.46 \\
\hline gdp & 20 & 57.11 & 10.80 & 1.72 & 1.88 & 5.14 & 23.32 \\
\hline equity & 10 & 6.25 & 83.67 & 0.55 & 2.45 & 2.83 & 4.22 \\
\hline inf & 20 & 6.35 & 82.33 & 0.60 & 3.13 & 3.15 & 4.41 \\
\hline ir & 10 & 10.43 & 21.89 & 58.83 & 2.57 & 5.67 & 0.58 \\
& 20 & 10.27 & 21.58 & 58.31 & 2.67 & 6.56 & 0.59 \\
\hline propprice & 10 & 5.53 & 2.54 & 1.35 & 83.57 & 6.15 & 0.84 \\
\hline- & 20 & 5.50 & 3.41 & 1.46 & 82.32 & 6.40 & 0.87 \\
\hline & 10 & 2.91 & 1.79 & 7.02 & 10.62 & 77.18 & 0.45 \\
& 20 & 2.70 & 2.17 & 7.89 & 12.59 & 74.17 & 0.45 \\
\hline- & 10 & 1.61 & 30.13 & 12.22 & 12.34 & 28.28 & 15.38 \\
\hline- & 20 & 1.09 & 28.40 & 14.04 & 12.98 & 35.36 & 8.09 \\
\hline
\end{tabular}

\subsection{Country-level analysis}

To test the robustness of the panel results, we conducted a country level analysis, using again a VAR approach. The model specification includes four variables (pod, $g d p, e q$, inf $)$. We include, in addition to the contemporary values of the variables, the first and fourth lag. We use a Choleski decomposition to identify the shocks and obtain estimates of the impulse-response functions. All the graphs are presented in Appendix III. The country-level results are in line with the evidence provided by the panel data analysis. As it is the case for the panel VAR, GDP responds negatively and significantly to a positive shock to the banking sector's probability of default for Korea, Sweden and Finland. The response is negative but not significant for the UK and Germany. This is not surprising since there were hardly any observations of pod in these two countries above the threshold level. In contrast to the panel VAR, the response of GDP is positive (but not very significant) for Norway and positive (but not significant) for Japan. The response of GDP to bank equity index is positive for Norway, Japan, Sweden and the UK (but not very significant for the last two countries) while it is not significant for Korea, Finland and Germany. On balance, the country-level analysis gives us some confidence in the robustness of the panel VAR results. 


\section{Concluding remarks}

In this paper we propose a definition of financial fragility as a combination of high probability of default (PD) and low bank profitability. This definition is modelbased in the sense that in an economy with maximising agents and banks as described in Goodhart et al (2004, 2005 and 2006 a) when, following a shock to an exogenous variable, aggregate endogenous default increases and banks' profits decrease, agents' welfare falls. We therefore think of an economy as being more financially fragile (or equivalently less financially stable) if agents' welfare decreases following an exogenous shock that induces distress in the financial system. We run comparative statics exercises based on a simplified version of the model. Specifically, we introduce a set of reduced-form equations describing households' behaviour to be able to calibrate the model against UK data. In this version, we use output as a proxy for agents' welfare. We simulate a series of shocks to the economy under two alternative assumptions: that banks are constrained by capital adequacy requirements and that they are not. When banks do not have to comply with CARs, shocks that induce a decline in banks profits and an increase in banks' default rates also produce a fall in GDP. Under the assumption of capital adequacy constraints, most shocks do not result in a fall in bank profits. The reason for this is that banks need to maintain or top up their capital, and they do this by choosing (riskier) investments that raise their profits. Finally, we investigate whether data support our claim that banking sector's distress induces welfare losses (i.e. a drop in GDP). The results of our panel VAR model, which includes banking sector and macroeconomic data of seven industrialised countries, are in line with those of the simulations. Shocks to banks' probability of default and equity values have a impact on output that is significant and has the expected sign.

\section{Appendix I: The model by Goodhart, Sunirand and Tsomocos (2005)}

The model has three heterogeneous banks, $b \in B=\{\gamma, \delta, \tau\}$, four private sector agents, $h \in H=\{\alpha, \beta, \theta, \phi\}$, a Central Bank and a regulator. The time horizon extends over two periods, $t \in T=\{1,2\}$ and two possible states in the second period, $s \in S=\{i, i i\}$. State $i$ is a normal/good state and occurs with probability $p$ while state $i$ i represents an extreme/crisis event.

Individual bank borrowers are assigned during the two periods, by history or by informational constraint, to borrow from a single bank: agents $\alpha, \beta$, and $\theta$ borrow from banks $\gamma, \delta$, and $\tau$, respectively. The remaining agent, $\phi$, represents the pool of depositors in this economy who supply funds to every bank. This limited participation assumption implies multiple active markets for deposits (by separate bank) and for loans (by borrower and bank). In addition, we assume a single, undifferentiated, interbank market where deficit banks borrow from surplus banks, and wherein the Central Bank conducts open market operations (OMOs). 
At $t=1$, loan, deposit and interbank markets open. Banks decide how much to lend/borrow in each market, expecting any one of the two possible future scenarios to occur. The Central Bank conducts OMOs in the interbank market. At $t=2$ all financial contracts are settled, subject to any defaults and/or capital requirements' violations, which are then penalised. At the end of the second period all banks are wound up.

\subsubsection{The interbank net borrowers' (banks $\gamma$ and $\tau$ ) optimisation prob- lems}

Bank $b \in\{\gamma, \tau\}$ maximises its payoff, which is a quadratic function of expected profits in the second period minus non-pecuniary penalties that it has to incur if it defaults on its deposit and interbank obligations. It also suffers a capital violation penalty proportional to its capital requirement violation. Formally, the optimisation problem of bank $b \in\{\gamma, \tau\}$ is as follows:

$\max _{\bar{m}^{b}, \mu^{b}, \mu_{d}^{b}, v_{s}^{b}, s \in S} \Pi^{b}=\sum_{s \in S} p_{s}\left[\pi_{s}^{b}-c_{s}^{b}\left(\pi_{s}^{b}\right)^{2}\right]-\sum_{s \in S} p_{s}\left[\begin{array}{c}\lambda_{k s}^{b} \max \left[0, \bar{k}^{b}-k_{s}^{b}\right]+ \\ \lambda_{s}^{b}\left[\mu^{b}-v_{s}^{b} \mu^{b}\right]+\lambda_{s}^{b}\left[\mu_{d}^{b}-v_{s}^{b} \mu_{d}^{b}\right]\end{array}\right]$

subject to

$$
\begin{aligned}
\bar{m}^{b}+A^{b} & =\frac{\mu^{b}}{(1+\rho)}+\frac{\mu_{d}^{b}}{\left(1+r_{d}^{b}\right)}+e_{0}^{b}+\text { Other }^{b} \\
v_{s}^{b} \mu^{b}+v_{s}^{b} \mu_{d}^{b}+\text { Others }^{b}+e_{0}^{b} & \leq v_{s b}^{h^{b}}\left(1+r^{b}\right) \bar{m}^{b}+\left(1+r^{A}\right) A^{b}, s \in S
\end{aligned}
$$

where,

$$
\begin{aligned}
\pi_{s}^{b} & =\Delta(3) \\
e_{s}^{b} & =e_{0}^{b}+\pi_{s}^{b}, s \in S \\
k_{s}^{b} & =\frac{e_{s}^{b}}{\bar{\omega} v_{s b}^{h^{b}}\left(1+r^{b}\right) \bar{m}^{b}+\widetilde{\omega}\left(1+r^{A}\right) A^{b}}, s \in S
\end{aligned}
$$

$\Delta(x) \equiv$ the difference between RHS and LHS of inequality $(x)$

$p_{s} \equiv$ probability that state $s \in S$ will occur,

$c_{s}^{b} \equiv$ coefficient of risk aversion in the utility function of bank $b \in B$,

$\lambda_{k s}^{b} \equiv$ capital requirements' violation penalties imposed on bank $b \in B$ in state $s \in S$,

$\bar{k}^{b} \equiv$ capital adequacy requirement for bank $b \in B$,

$\lambda_{s}^{b} \equiv$ default penalties on bank $b \in B$,

$\mu^{b} \equiv$ amount of money that bank $b \in\{\gamma, \tau\}$ owes in the interbank market,

$\mu_{d}^{b} \equiv$ amount of money that bank $b \in B$ owes in the deposit market,

$v_{s}^{b} \equiv$ repayment rates of bank $b \in B$ to all its creditors in state $s \in S$,

$\bar{m}^{b} \equiv$ amount of credit that bank $b \in B$ extends in the loan market, 
$A^{b} \equiv$ the value of market book held by bank $b \in B$,

$e_{s}^{b} \equiv$ amount of capital that bank $b \in B$ holds in state $s \in\{0\} \cup S$,

Others $s^{b} \equiv$ the 'others' item in the balance sheet of bank $b \in B$,

$r^{b} \equiv$ lending rate offered by bank $b \in B$,

$r_{d}^{b} \equiv$ deposit rate offered by bank $b \in B$,

$\rho \equiv$ interbank rate,

$r^{A} \equiv$ the rate of return on market book,

$v_{s b}^{h^{b}} \equiv$ repayment rates of agent $h^{b} \in H^{b}=\left\{\alpha^{\gamma}, \beta^{\delta}, \theta^{\tau}\right\}$ to his nature-selected

bank $b \in B$ in the consumer loan market,

$\bar{\omega} \equiv$ risk weight on consumer loans, and

$\widetilde{\omega} \equiv$ risk weight on market book.

Equation (2) implies that, at $t=1$, the assets of bank $b \in\{\gamma, \tau\}$, which consist of its credit extension and market book investment, must be equal to its liabilities obtained from interbank and deposit borrowing and its initial equity endowment, where 'Others ${ }^{b}$ ' represents the residual. Equations (3) and (4) then show that, dependent on which of the $s \in S$ actually occurs, the profit that bank $b$ incurs in the second period is equal to the difference between the amount of money that it receives from its asset investment and the amount that it has to repay on its liabilities, adjusted appropriately for default in each market. As shown in equation (5), the profit earned is then added to its initial capital, which in turn becomes its capital in the second period. Finally, equation (6) implies that the capital to asset ratio of bank $b$ in state $s \in S$ is equal to its capital in state $s$ divided by its risk-weighted assets in the corresponding state.

\subsubsection{The interbank net lender's (bank $\delta$ ) optimisation problem}

Bank $\delta$, unlike the other two banks, is a net lender in the interbank market. Thus it suffers only a default penalty in the deposit market. Formally, bank $\delta$ 's optimisation problem is as follows:

$\max _{\bar{m}^{\delta}, d^{\delta}, \mu_{d}^{\delta}, v_{s}^{\delta}, s \in S} \Pi^{\delta}=\sum_{s \in S} p_{s}\left[\pi_{s}^{\delta}-c_{s}^{\delta}\left(\pi_{s}^{\delta}\right)^{2}\right]-\sum_{s \in S} p_{s}\left[\lambda_{k s}^{\delta} \max \left[0, \bar{k}^{\delta}-k_{s}^{\delta}\right]+\lambda_{s}^{\delta}\left[\mu_{d}^{\delta}-v_{s}^{\delta} \mu_{d}^{\delta}\right]\right]$

subject to

$$
\begin{aligned}
A^{\delta}+d^{\delta}+\bar{m}^{\delta} & =e_{0}^{\delta}+\frac{\mu_{d}^{\delta}}{\left(1+r_{d}^{\delta}\right)}+\text { Others }^{\delta} \\
v_{s}^{\delta} \mu_{d}^{\delta}+\text { Others }^{\delta}+e_{0}^{\delta} & \leq v_{s \delta}^{\beta^{\delta}} \bar{m}^{\delta}\left(1+r^{\delta}\right)+A^{\delta}\left(1+r^{A}\right)+\widetilde{R}_{s} d^{\delta}(1+\rho)
\end{aligned}
$$

where,

$$
\begin{aligned}
\pi_{s}^{\delta} & =\Delta(8) \\
e_{s}^{\delta} & =e_{0}^{\delta}+\pi_{s}^{\delta} \\
k_{s}^{\delta} & =\frac{e_{s}^{\delta}}{\bar{\omega} v_{s \delta}^{\beta^{\delta}}\left(1+r^{\delta}\right) \bar{m}^{\delta}+\omega \widetilde{R}_{s} d^{\delta}(1+\rho)+\widetilde{\omega}\left(1+r^{A}\right) A^{\delta}}
\end{aligned}
$$


$d^{\delta} \equiv$ bank $\delta$ 's investment in the interbank market,

$\widetilde{R}_{s} \equiv$ the rate of repayment that bank $\delta$ expects to get from its interbank investment, and

$\omega \equiv$ risk weight on interbank investment.

The budget set of bank $\delta$ is similar to those of the other two banks except that it invests in, instead of borrows from, the interbank market. Moreover, its riskweighted assets in the second period, as shown in equation (11), also includes bank $\delta$ 's expected return on its interbank investment.

\subsection{Central Bank and Regulator}

The Central Bank conducts monetary policy by engaging in open market operations in the interbank market. It can either set its base money $(M)$ as its monetary policy instrument, allowing the interbank rate to be determined endogenously, or it can fix the interbank rate and let its base money adjust endogenously to clear the interbank market.

The regulator sets capital adequacy requirements for all banks $\left(\bar{k}^{b}\right)$ and imposes penalties on their failure to meet such requirements $\left(\lambda_{k s}^{b}\right)$ and on default on their financial obligations in the deposit and interbank markets $\left(\lambda_{s}^{b}\right)$. Finally, the regulator sets the risk weights on consumer loan, interbank and market book investment $(\bar{\omega}, \omega, \widetilde{\omega})$.

\subsection{Household sector}

Each household borrower, $h^{b}=\left\{\alpha^{\gamma}, \beta^{\delta}, \theta^{\tau}\right\}$, demands consumer loans from his nature-selected bank and chooses whether to default on his loans in state $s \in S$. The remaining agent, $\phi$, supplies his deposits to each bank $b$. As mentioned, we do not explicitly model the optimisation problems of households but assume the following reduced-form equations.

\subsubsection{Household borrowers' demand for Loans}

Because of the limited participation assumption in every consumer loan market, each household's demand for loans is a negative function of the lending rate offered by his nature-selected bank. In addition, his demand for loans also depends positively on the expected GDP in the subsequent period. So we implicitly assume that household borrowers rationally anticipate GDP in both states of the next period, which then determines their expected future income, and adjust their loan demand in the initial period accordingly in order to smooth their consumption over time. The money demand function manifests the standard Hicksian elements whereby it responds positively to current and expected income and negatively to interest rates. In particular, household $h^{b}$ 's loan demand from his nature-selected bank $b$, $\forall h^{b} \in H^{b}$, and $b \in B$ is as follows:

$$
\ln \left(\mu^{h^{b}}\right)=a_{h^{b}, 1}+a_{h^{b}, 2} \ln \left[p\left(G D P_{i}\right)+(1-p) G D P_{i i}\right]+a_{h^{b}, 3} r^{b}
$$

where, 
$\mu^{h^{b}} \equiv$ amount of money that agent $h^{b} \in H^{b}$ chooses to owe in the loan market of bank $b \in B$, and

$G D P_{s} \equiv$ Gross Domestic Product in state $s \in S$ of the second period.

\subsubsection{Deposit Supply}

Unlike the loan markets, we do not assume limited participation in the deposit markets. This implies that $\phi$ can choose to diversify his deposits with every bank. Thus, Mr. $\phi$ 's deposit supply with bank $b$ depends not only on the deposit rate offered by $b$ but also on the rates offered by the other banks. Moreover, since banks can default on their deposit obligations, the expected rate of return on deposit investment of $\phi$ with each bank has to be adjusted appropriately for each bank's corresponding expected default rate. Finally, $\phi$ 's deposit supply is a positive function of the expected GDP. In symbols, $\phi$ 's deposit supply function with bank $b$ is as follows:

$$
\begin{aligned}
\ln \left(d_{b}^{\phi}\right)= & z_{b, 1}+z_{b, 2} \ln \left[p\left(G D P_{i}\right)+(1-p) G D P_{i i}\right]+z_{b, 3}\left[r_{d}^{b}\left(p v_{i}^{b}+(1-p) v_{i i}^{b}\right)\right] \\
& +z_{b, 4} \sum_{\dot{b} \neq b \in B}\left[r_{d}^{\hat{b}}\left(p v_{i}^{\hat{b}}+(1-p) v_{i i}^{\hat{b}}\right)\right]
\end{aligned}
$$

where,

$d_{b}^{\phi} \equiv$ amount of money that agent $\phi$ chooses to deposit with bank $b \in B$.

\subsubsection{Households' Loan Repayment Rates}

We assume that each household's repayment rate on his loan obligation to his nature-selected bank in state $s \in S$ is a positive function of the corresponding GDP level as well as the aggregate credit supply in the economy. The latter variable captures the effect of 'credit crunch' in the economy whereby a fall in the overall credit supply in the economy aggravates the default probability of every household. ${ }^{21}$ Specifically, the functional form of the repayment rate of household $h^{b}$, $\forall h^{b} \in H^{b}$, to his nature-selected bank $b \in B$, in state $s \in S$ is as follows:

$$
\ln \left(v_{s b}^{h^{b}}\right)=g_{h^{b}, s, 1}+g_{h^{b}, s, 2} \ln \left(G D P_{s}\right)+g_{h^{b}, s, 3}\left[\ln \left(\bar{m}^{\gamma}\right)+\ln \left(\bar{m}^{\delta}\right)+\ln \left(\bar{m}^{\tau}\right)\right]
$$

\subsection{GDP}

As can be seen from equations (12) to (14), we have assumed that households' actions depend on their expected GDP in the second period. So, in this section we endogenise GDP in both states of the second period. We assume that GDP in each state is a positive function of the aggregate credit supply available in the previous period. Since the Modigliani-Miller proposition does not hold in our model ${ }^{22}$, higher credit extension as a result of loosening monetary policy, or any other shocks, generates a positive real balance effect that raises consumption demand and ultimately

\footnotetext{
${ }^{21}$ Higher interest rates, given that households are liquidity constrained, ultimately increase their debt obligations in the future. Hence, defaults rise.

${ }^{22}$ See Goodhart et al. (2003) for an extensive discussion.
} 
GDP. In particular, the following functional form for GDP in state $s \in S$ of the second period $\left(G D P_{s}\right)$ holds.

$$
\ln \left(G D P_{s}\right)=u_{s, 1}+u_{s, 2}\left[\ln \left(\bar{m}^{\gamma}\right)+\ln \left(\bar{m}^{\delta}\right)+\ln \left(\bar{m}^{\tau}\right)\right]+u_{s, 3}\left[\ln \left(e_{s}^{\gamma}\right)+\ln \left(e_{s}^{\delta}\right)+\ln \left(e_{s}^{\tau}\right)\right]
$$

\subsection{Market Clearing Conditions}

There are seven active markets in the model (three consumer loan, three deposit and one interbank markets). Each of these markets determines an interest rate that equilibrates demand and supply in equilibrium. ${ }^{23}$

$$
\begin{gathered}
1+r^{b}=\frac{\mu^{h^{b}}}{\bar{m}^{b}}, h^{b} \in H^{b}, \forall b \in B \quad \text { (i.e. bank b's loan market clears) } \\
1+r_{d}^{b}=\frac{\mu_{d}^{b}}{d_{b}^{\phi}}, \forall b \in B \quad \text { (i.e. bank b's deposit market clears) } \\
1+\rho=\frac{\mu^{\gamma}+\mu^{\tau}}{M+d^{\delta}} \quad \text { (i.e. interbank market clears) }
\end{gathered}
$$

We note that these interest rates, i.e. $r^{b}, r_{d}^{b}$, and $\rho, b \in B$, are the ex ante nominal interest rates that incorporate default premium since default is permitted in equilibrium. Their effective (ex post) interest rates have to be suitably adjusted to account for default in their corresponding markets. ${ }^{24}$

\subsection{Equilibrium}

The equilibrium in this economy is characterised by a vector of all choice variables of active agents such that banks maximise their payoff function subject to their budget constraints, all markets clear (i.e. conditions 16, 17, and 18 are satisfied), bank $\delta$ is correct in its expectation about the repayment rates that it gets from its interbank investment, and, finally, loan demand, deposit supply, repayments rates, and GDP in both states $s$ satisfy the reduced form equations (12)-(15).

\section{Appendix II: Simulations}

\subsection{Case I: Banks face CARs}

A negative shock to capital endowment

\footnotetext{
${ }^{23}$ The interest rate formation mechanism is identical to the offer-for-sale mechanism in Dubey and Shubik (1978). The denominator of each of the expressions (15-17) represents the supply side whereas the numerator divided by $(1+r), r \in\left\{r^{b}, r_{d}^{b}, \rho\right\}, b \in B$ corresponds to the demand. Note that this interest rate formation mechanism is well-defined both in, and out of, equilibrium.

${ }^{24}$ For more on the method of calculating the ex post interest rates, see Shubik and Tsomocos (1992).
} 
We now turn to the analysis of the impact of a negative shock to the capital endowment of bank $\delta$ in the initial period. In particular, we decrease capital by $5 \%$ (from 35,671 to 33,890 million pounds).

\begin{tabular}{|c|c|c|c|c|c|c|c|c|c|c|c|c|c|}
\hline & \multicolumn{3}{|c|}{ Interest rates } & \multirow{2}{*}{$\pi_{i}^{b}$} & \multirow{2}{*}{$\pi_{i i}^{b}$} & \multirow{2}{*}{$e_{i}^{b}$} & \multirow{2}{*}{$e_{i i}^{b}$} & \multirow{2}{*}{$k_{i}^{b}$} & \multirow{2}{*}{$k_{i i}^{b}$} & \multirow{2}{*}{$v_{i}^{b}$} & \multirow{2}{*}{$v_{i i}^{b}$} & \multirow[b]{2}{*}{$G D P_{i}$} & \multirow[b]{2}{*}{$G D P_{i i}$} \\
\hline & $r_{d}^{b}$ & $r^{b}$ & $\rho$ & & & & & & & & & & \\
\hline Bank $\delta$ & -9.4 & -4 & \multirow{3}{*}{-7.8} & 0.13 & 0.2 & -4.5 & -5.1 & -3.8 & -4.4 & 0.04 & 0.07 & \multirow{3}{*}{-0.56} & \multirow{3}{*}{-0.62} \\
\hline Bank $\gamma$ & -7.8 & -3.9 & & 0.2 & 0.4 & 0.04 & 0.1 & 0.7 & 0.8 & -0.03 & -0.03 & & \\
\hline Bank $\tau$ & -7.8 & -4 & & 0.03 & 0.04 & 0.007 & 0.006 & 0.6 & 0.7 & -0.02 & -0.01 & & \\
\hline
\end{tabular}

The fall in $\delta$ 's capital endowment causes a contraction in the funds available for loans to other banks and to households. But loan demand falls as well, as expected GDP, which is a function, among other things, of banks' equity value, decreases considerably. As a result, the interest rate in the interbank market $\rho$ and on bank $\delta$ 's loans to households $r^{\delta}$ decrease significantly, by $7.8 \%$ and $4 \%$ respectively (i.e. from $4.4 \%$ to $4 \%$ the first one and from $7.5 \%$ to $8.7 \%$ the second one). The interest rate on bank $\delta$ 's deposits also decreases.

Banks $\gamma$ and $\tau$ respond to the lower expected households' wealth (and therefore to their higher default rates) by decreasing their lending and, as a consequence, their demand of funds in the interbank and in the deposit markets. This causes the interest rates in these markets to drop.

The decrease in aggregate bank lending and in the loan rates is the result of the effect on demand and supply of credit of the initial shock to capital. All banks have less available funds: bank $\delta$ because of the fall in its own capital, the other banks because they can borrow less in the interbank market. Also, bank $\delta$ is willing to extend fewer loans to avoid its capital-to-asset ratio decreasing dramatically. A second-round effect on loan supply comes through the effect of the fall in lending and in bank $\delta$ 's capital on future GDP and hence in households' repayment rates, as it happened in the previous simulation. At the same time loan supply decreases, demand for credit also drops considerably due to the repercussion of the lower value of bank $\delta$ 's equity on expected GDP. This fall in demand explains the lower loan rates.

The effect of an exogenous shock to bank $\delta$ 's capital on the other key variables presented in Table 2 can be understood by noting that banks maximise their utility by equating the marginal benefit from profits with the marginal cost from default and capital violation penalties. Hence, in trying to achieve maximal utility, banks face a trade-off. On the one hand, higher profits increase banks' utility both directly and by raising banks' capital-to-asset ratios. On the other hand, to obtain higher profits, other things equal, banks need to take more risk, i.e. to increase their default rates (equivalently to decrease their repayment rates). But lower repayment 
rates translate into higher costs in the form of higher expected default penalties. Following a negative shock to bank $\delta$ 's capital, the default probabilities of households also increase and, as a consequence, the values of banks' risk-weighted assets decrease. In this simulation exercise, banks' profits increase, as the effect of lower lending rates is offset by the lower cost of funds and by banks' lower repayment rates. Bank $\delta$ 's capital and capital-to-asset ratio both decrease considerably in the second period, as profits are not sufficiently high to replenish lost capital, while the capital holding and the capital-to-asset ratios of banks $\gamma$ and $\tau$ increase.

\section{An increase in default penalties}

We now analyse the consequences of the regulator increasing the penalties on banks who default on their debt (to depositors and other banks). We assume a 2 percent increase in both states of the world. (from 0.9 to approximately 0.92 in the state 1 and from 1.1 to approximately 1.12 in state 2 ). Since defaulting is now more costly, banks increase their repayment rates (the percentage changes of $v_{i}^{b}$ and $v_{i i}^{b}$ are positive for all banks, as shown in Table 3). Banks' more prudent investment choices induce a decline in profits (and, therefore, in capital and capital to riskweighted asset ratios). Because banks $\gamma$ and $\tau$ increase their repayment rates to all creditors considerably, bank $\delta$ is willing to invest more in the interbank market. As a result, the interbank rate $\rho$ decreases. Since $\gamma$ and $\tau$ are able to borrow more and at a lower cost from the interbank market, their demand of deposits decreases and so do their deposit rates. The overall level of aggregate credit to households decreases as a result of the negative households' wealth effect of lower bank equity values.

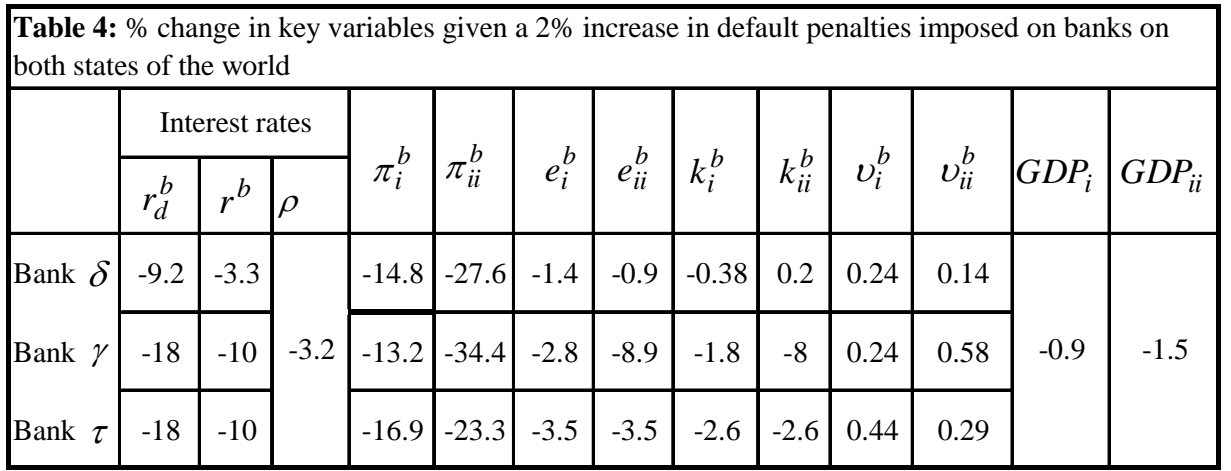

\section{A negative shock to deposit supply}

The last scenario we analyse in this section refers to a negative deposit supply shock to bank $\delta$ in the initial period. In particular, we simulate a decrease in the deposit supply of $\phi$ with bank $\delta\left(z_{\delta, 1}\right)$ of approximately 3 percent. Not surprisingly, the changes of the variables in Table 4 are qualitatively similar to the ones resulting from the decrease in the Central Bank's funds injected in the interbank market, since the shock to deposits represents a change in the overall broad money supply. The difference is that in this case the shock is concentrated on bank $\delta$. To maintain its profitability, bank $\delta$ decreases its repayment rate in both states of the world. 
Given $\delta$ 's higher probability of default, its deposit rate increases by more than the deposit rates of the other two banks. GDP decreases significantly in both states of the world due to lower bank credit.

\begin{tabular}{|c|c|c|c|c|c|c|c|c|c|c|c|c|c|}
\hline & \multicolumn{3}{|c|}{ Interest rates } & \multirow[b]{2}{*}{$\pi_{i}^{b}$} & \multirow[b]{2}{*}{$\pi_{i i}^{b}$} & \multirow[b]{2}{*}{$e_{i}^{b}$} & \multirow[b]{2}{*}{$e_{i i}^{b}$} & \multirow[b]{2}{*}{$k_{i}^{b}$} & \multirow[b]{2}{*}{$k_{i i}^{b}$} & \multirow[b]{2}{*}{$v_{i}^{b}$} & \multirow[b]{2}{*}{$v_{i i}^{b}$} & \multirow[b]{2}{*}{$G D P_{i}$} & \multirow[b]{2}{*}{$G D P_{i i}$} \\
\hline & $r_{d}^{b}$ & $r^{b}$ & $\rho$ & & & & & & & & & & \\
\hline Bank $\delta$ & 9 & 10 & \multirow{3}{*}{7.9} & 0.5 & 0.8 & 0.05 & 0.03 & 3.1 & 3.3 & -0.1 & -0.1 & \multirow{3}{*}{-0.59} & \multirow{3}{*}{-0.57} \\
\hline Bank $\gamma$ & 7.9 & 11 & & 0.4 & 1 & 0.09 & 0.27 & 1.7 & 2 & 0.02 & -0.05 & & \\
\hline Bank $\tau$ & 7.9 & 11 & & 0.08 & 0.1 & 0.02 & 0.02 & 1.5 & 1.6 & 0.01 & -0.04 & & \\
\hline
\end{tabular}

We now present further simulation exercises based on an economy where banks do not have to comply with capital adequacy requirements. Table 6 shows the effect of a negative shock to the capital endowment of bank $\delta$ in the initial period. In Table 7 we report the impact on key variables of a $2 \%$ increase in default penalties imposed on banks on both states of the world and, finally, Table 8 shows the percentage changes in key variables given a $3 \%$ decrease in the deposit supply to bank $\delta$ in the initial period.

As already discussed, the results of this set of simulations are quite similar to the ones conducted under the assumption that CARs are in place. A notable difference is the effect on bank profitability. When banks do face penalties for violating their capital constraint they have a lower incentive to raise capital (through retained earnings). Since the value of banks' equity partly determines the level of future output, the decrease in GDP is higher for the simulations done under the assumption of no CARs than for the previous ones.

\subsection{Case II: Banks are not constrained by CARs}

In the three following tables we present the results of a negative shock to capital endowment, an increase in default penalties and, finally, a negative shock to the supply of deposits under the assumption that banks are not constrained by a capital adequacy requirement. 


\begin{tabular}{|c|c|c|c|c|c|c|c|c|c|c|c|c|c|}
\hline & \multicolumn{3}{|c|}{ Interest rates } & \multirow{2}{*}{$\pi_{i}^{b}$} & \multirow{2}{*}{$\pi_{i i}^{b}$} & \multirow{2}{*}{$e_{i}^{b}$} & \multirow{2}{*}{$e_{i i}^{b}$} & \multirow[b]{2}{*}{$k_{i}^{b}$} & \multirow[b]{2}{*}{$k_{i i}^{b}$} & \multirow{2}{*}{$v_{i}^{b}$} & \multirow[b]{2}{*}{$v_{i i}^{b}$} & \multirow[b]{2}{*}{$G D P_{i}$} & \multirow[b]{2}{*}{$G D P_{i i}$} \\
\hline & $r_{d}^{b}$ & $r^{b}$ & $\rho$ & & & & & & & & & & \\
\hline Bank $\delta$ & -1.1 & -4.4 & \multirow{3}{*}{-9} & -0 & -0.02 & -4.6 & -5.2 & -3.8 & -4.4 & 0.05 & 0.08 & \multirow{3}{*}{-0.57} & \multirow{3}{*}{-0.64} \\
\hline Bank $\gamma$ & -9 & -4.7 & & 0 & 0 & 0.001 & 0.003 & 0.6 & 0.7 & -0.03 & -0.02 & & \\
\hline Bank $\tau$ & -9 & -4.6 & & -0 & -0 & -0 & 0 & 0.6 & 0.7 & -0.02 & -0.01 & & \\
\hline
\end{tabular}

\begin{tabular}{|c|c|c|c|c|c|c|c|c|c|c|c|c|c|}
\hline & Inte & rest $r$ & & & & & & & & & & & \\
\hline & $r_{d}^{b}$ & $r^{b}$ & $\rho$ & $\pi_{i}^{D}$ & $\pi_{i i}^{\nu}$ & $e_{i}^{U}$ & $e_{i i}^{U}$ & $k_{i}^{D}$ & $k_{i i}^{D}$ & $v_{i}^{U}$ & $v_{i i}^{D}$ & $G D P_{i}$ & $G D P_{i i}$ \\
\hline Bank $\delta$ & -1.1 & -4 & \multirow{3}{*}{-21} & -18 & -22 & -1.5 & -0.9 & -0.4 & 0.24 & 0.26 & 0.15 & \multirow{3}{*}{-0.9} & \multirow{3}{*}{-1.7} \\
\hline Bank $\gamma$ & -21 & -12 & & -18 & -22 & -2.9 & -10.7 & -2 & -9.8 & 0.26 & 0.6 & & \\
\hline Bank $\tau$ & -21 & -12 & & -18 & -22 & -3.5 & -3.6 & -2.6 & -2.6 & 0.44 & 0.29 & & \\
\hline
\end{tabular}

Table 8: \% change in key variables given a 3\% decrease in deposit supply to bank $\square$ at $\mathrm{t}=1$ (no CARs)

\begin{tabular}{|c|c|c|c|c|c|c|c|c|c|c|c|c|c|}
\hline & \multicolumn{3}{|c|}{ Interest rates } & \multirow[b]{2}{*}{$\pi_{i}^{b}$} & \multirow[b]{2}{*}{$\pi_{i i}^{b}$} & \multirow[b]{2}{*}{$e_{i}^{b}$} & \multirow[b]{2}{*}{$e_{i i}^{b}$} & \multirow[b]{2}{*}{$k_{i}^{b}$} & \multirow[b]{2}{*}{$k_{i i}^{b}$} & \multirow[b]{2}{*}{$v_{i}^{b}$} & \multirow[b]{2}{*}{$v_{i i}^{b}$} & \multirow[b]{2}{*}{$G D P_{i}$} & \multirow[b]{2}{*}{$G D P_{i i}$} \\
\hline & $r_{d}^{b}$ & $r^{b}$ & $\rho$ & & & & & & & & & & \\
\hline Bank $\delta$ & 10 & 11 & \multirow{3}{*}{8.8} & 0.02 & 0.04 & 0 & 0 & 3.1 & 3.2 & -0.1 & -0.1 & \multirow{3}{*}{-0.6} & \multirow{3}{*}{-0.6} \\
\hline Bank $\gamma$ & 8.8 & 12 & & 0 & 0 & 0 & 0 & 1.6 & 1.7 & 0.02 & -0.02 & & \\
\hline Bank $\tau$ & 8.8 & 12 & & -0 & -0 & -0 & -0 & 1.5 & 1.6 & 0.01 & -0.04 & & \\
\hline
\end{tabular}




\section{Appendix III: Figures}



Figure 2: Impulse responses of a $\operatorname{VAR}(3)$ including pod, gdp, equity and inf 




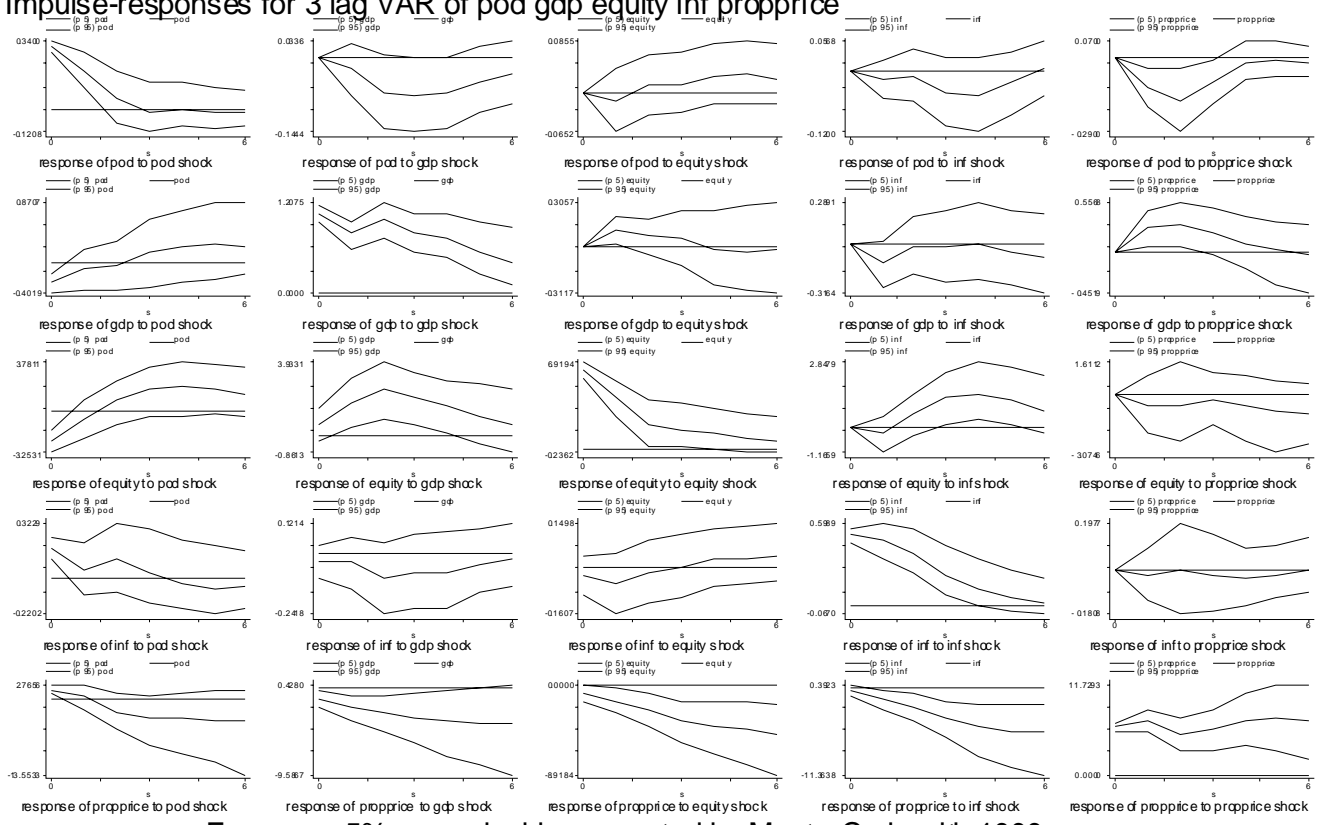

Errors are $5 \%$ on each side generated by Monte-Carlo with 1000 reps

Figure 3: Impulse responses of a $\operatorname{VAR}(3)$ including pod, gdp, equity, inf, propprice 


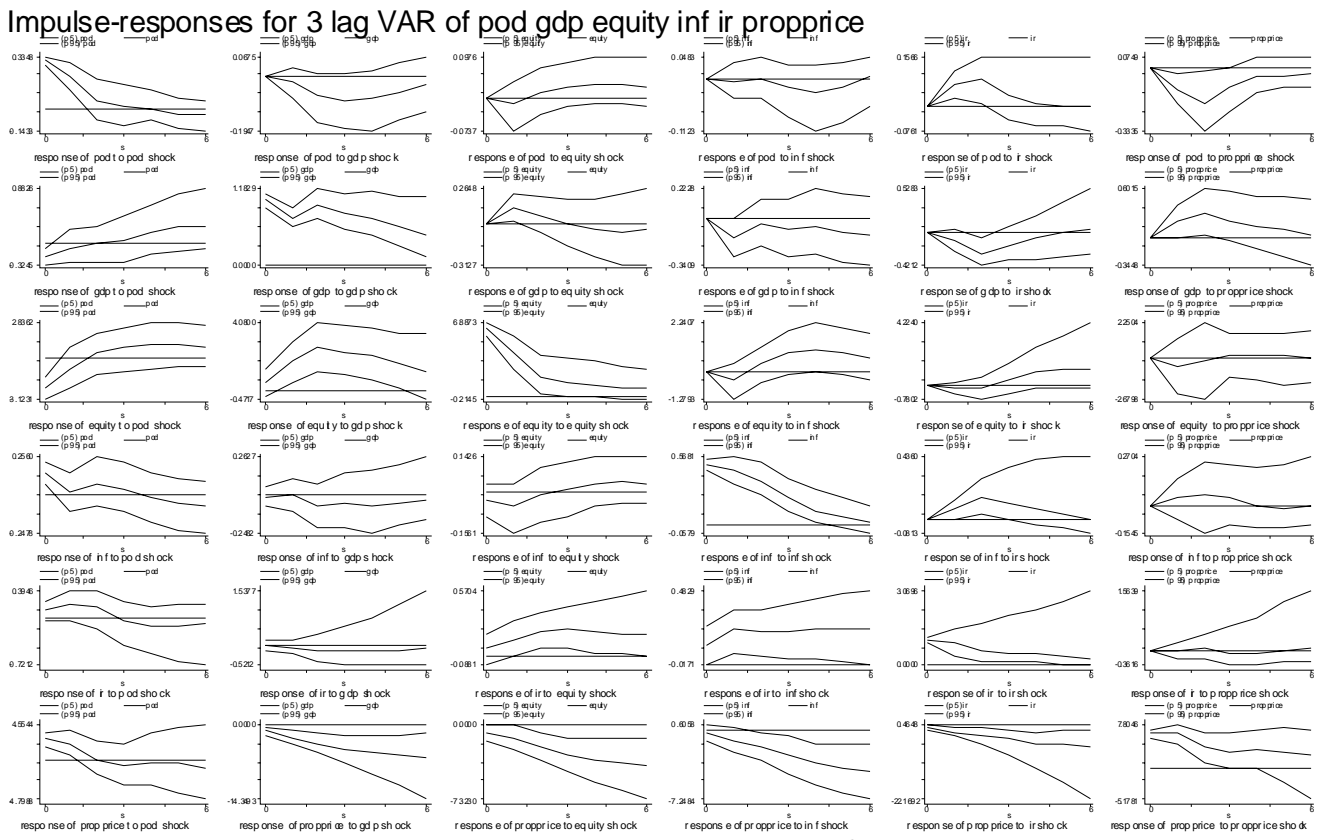

Errors are $5 \%$ on each side generated by Monte-Carlo with 1000 reps

Figure 4: Impulse responses of a $\operatorname{VAR}(3)$ with pod, gdp, equity, inf, ir, propprice 


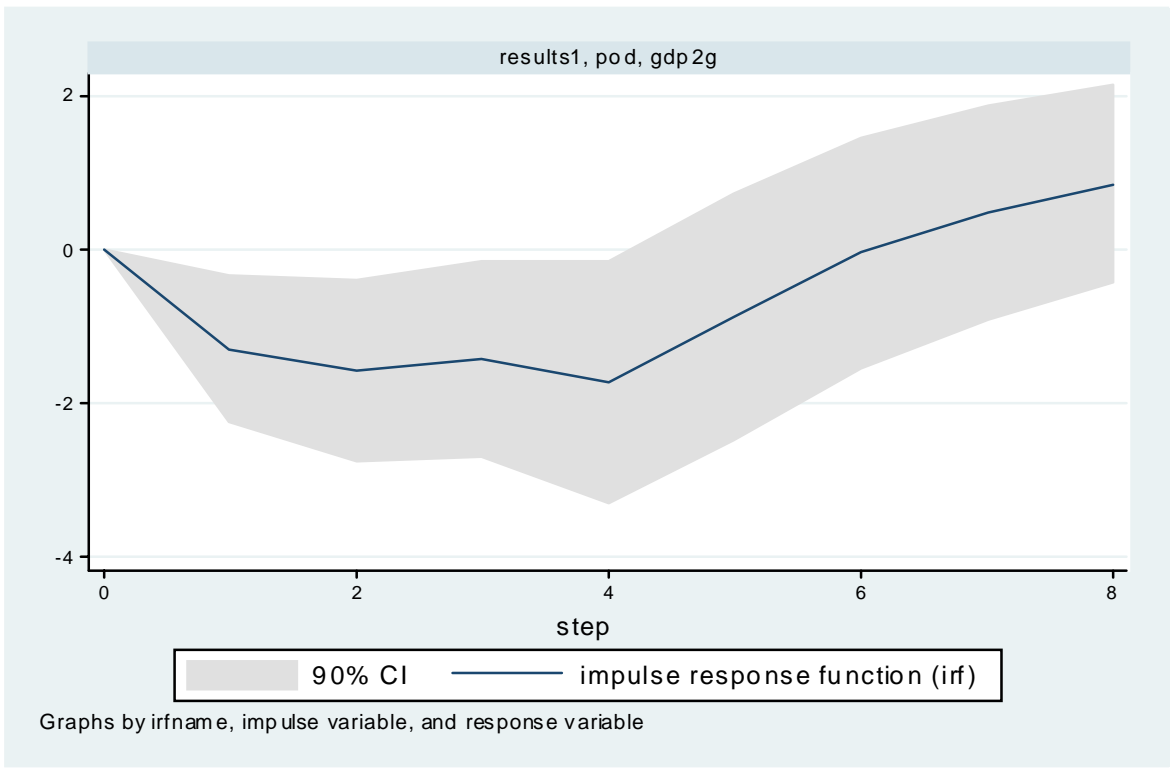

Figure 5: Impulse-response of GDP growth to bank POD (Korea)

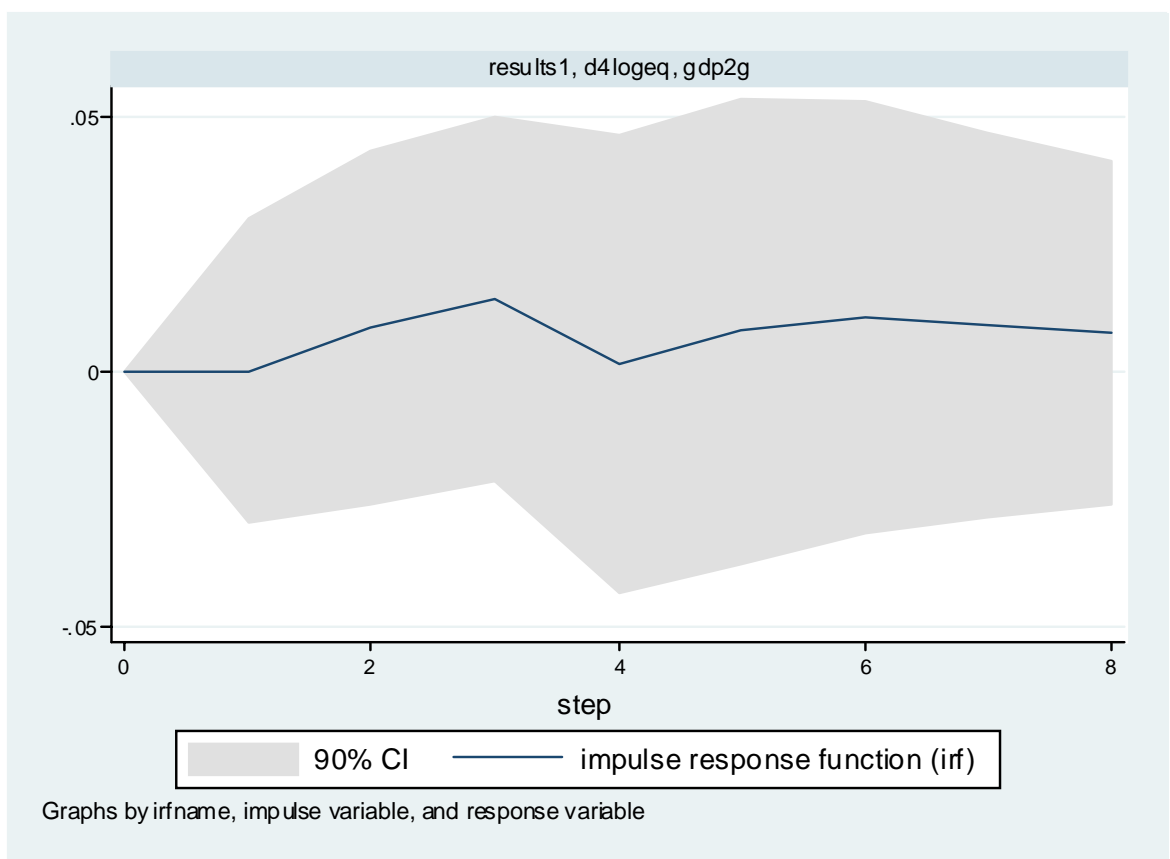

Figure 6: Impulse-response of GDP growth to bank equity index (Korea) 
sweden, pod, gdp $2 \mathrm{~g}$

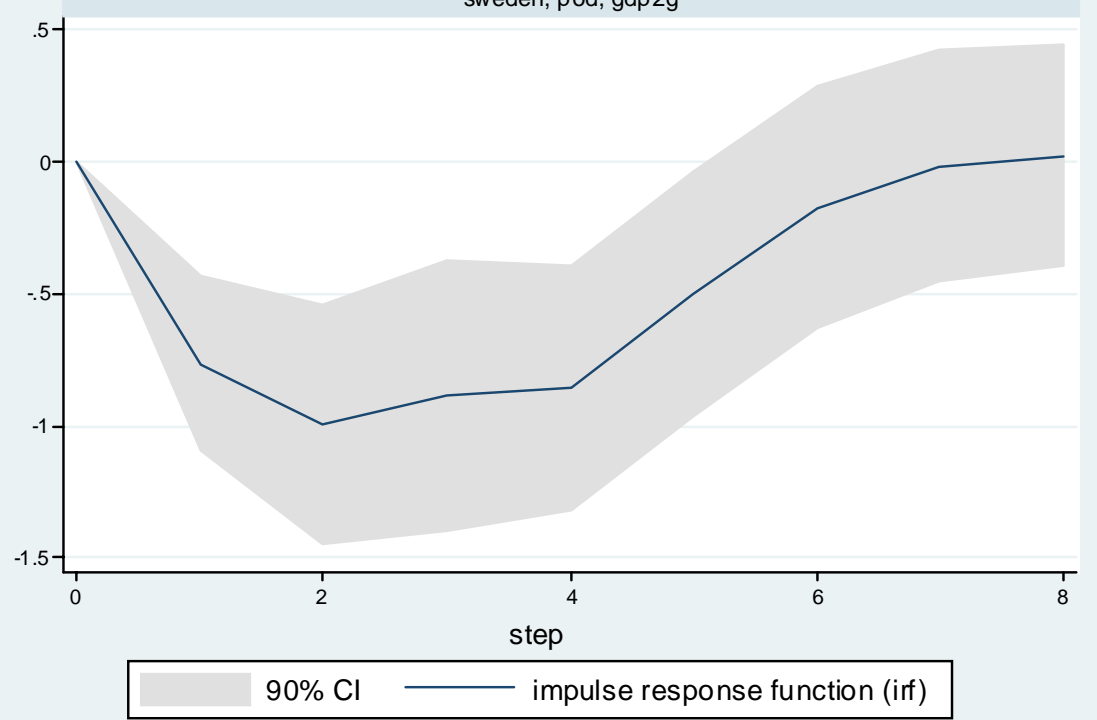

Graphs by irfname, impulse variable, and response variable

Figure 7: Impulse-response of GDP growth to bank POD (Sweden) 


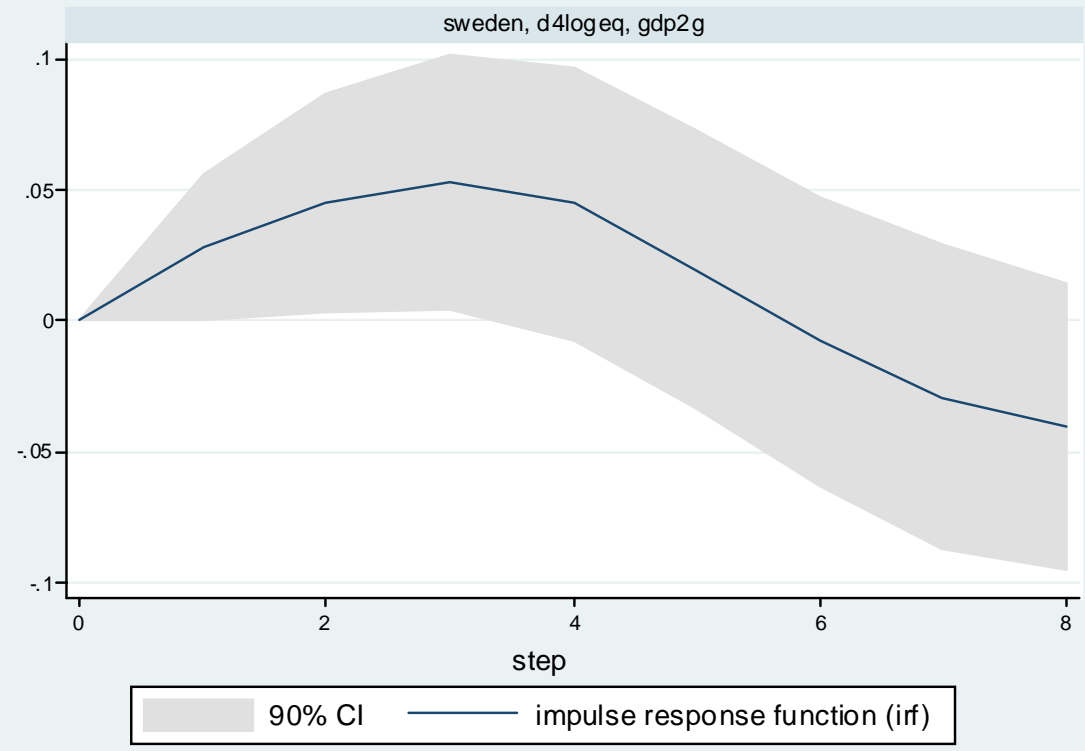

Graphs by irfname, impulse variable, and response variable

Figure 8: Impulse-response of GDP growth to bank equity index (Sweden) 




Figure 9: Impulse-response of GDP growth to bank POD (Norway) 


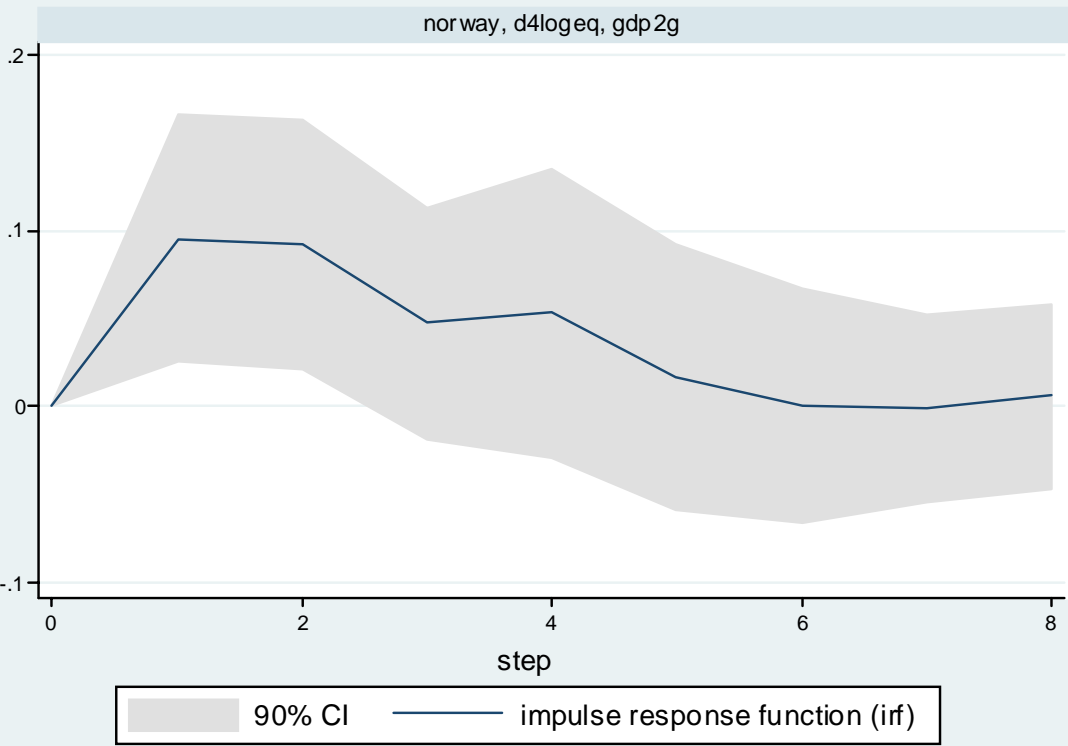

Graphs by irfname, impulse variable, and response variable

Figure 10: Impulse-response of GDP growth to bank equity index (Norway) 




Figure 11: Impulse-response of GDP growth to bank POD (Finland) 


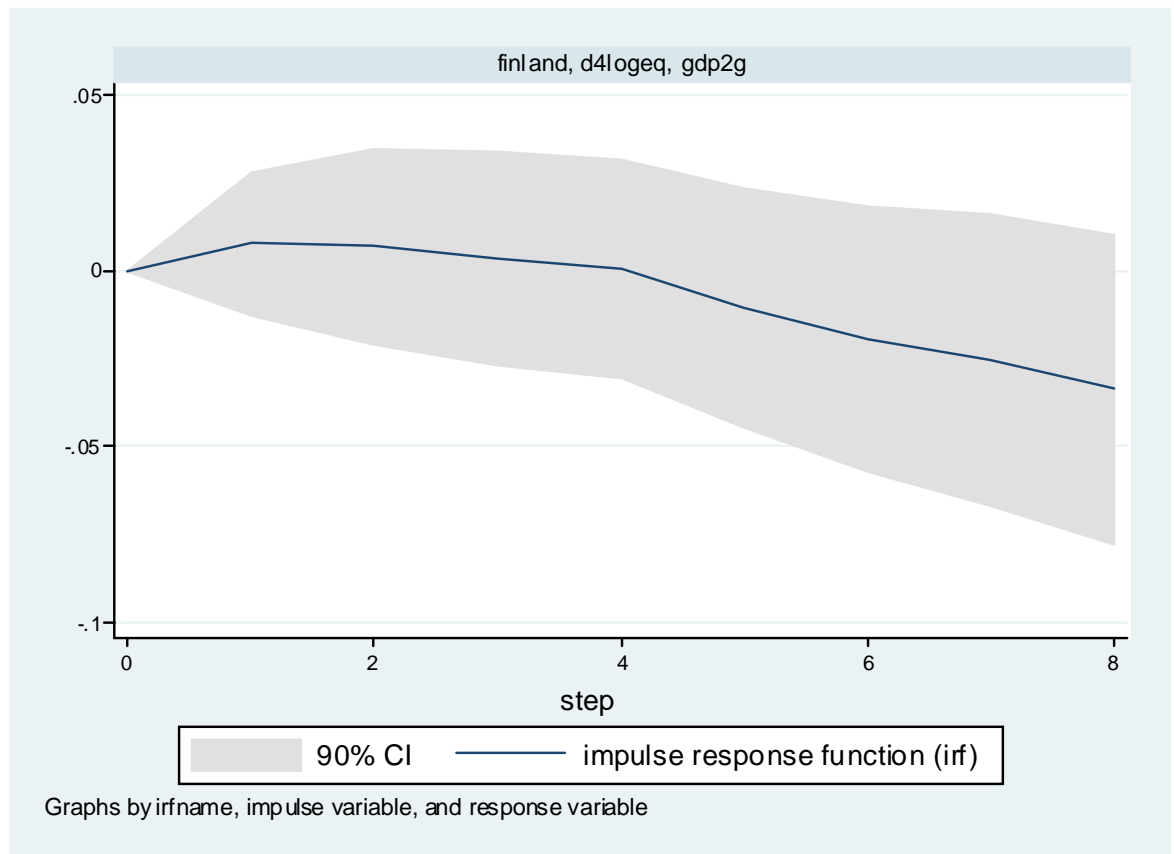

Figure 12: Impulse-response of GDP growth to bank equity index (Finland) 




Figure 13: Impulse-response of GDP growth to bank POD (UK) 




Figure 14: Impulse-response of GDP growth to bank equity index (UK) 


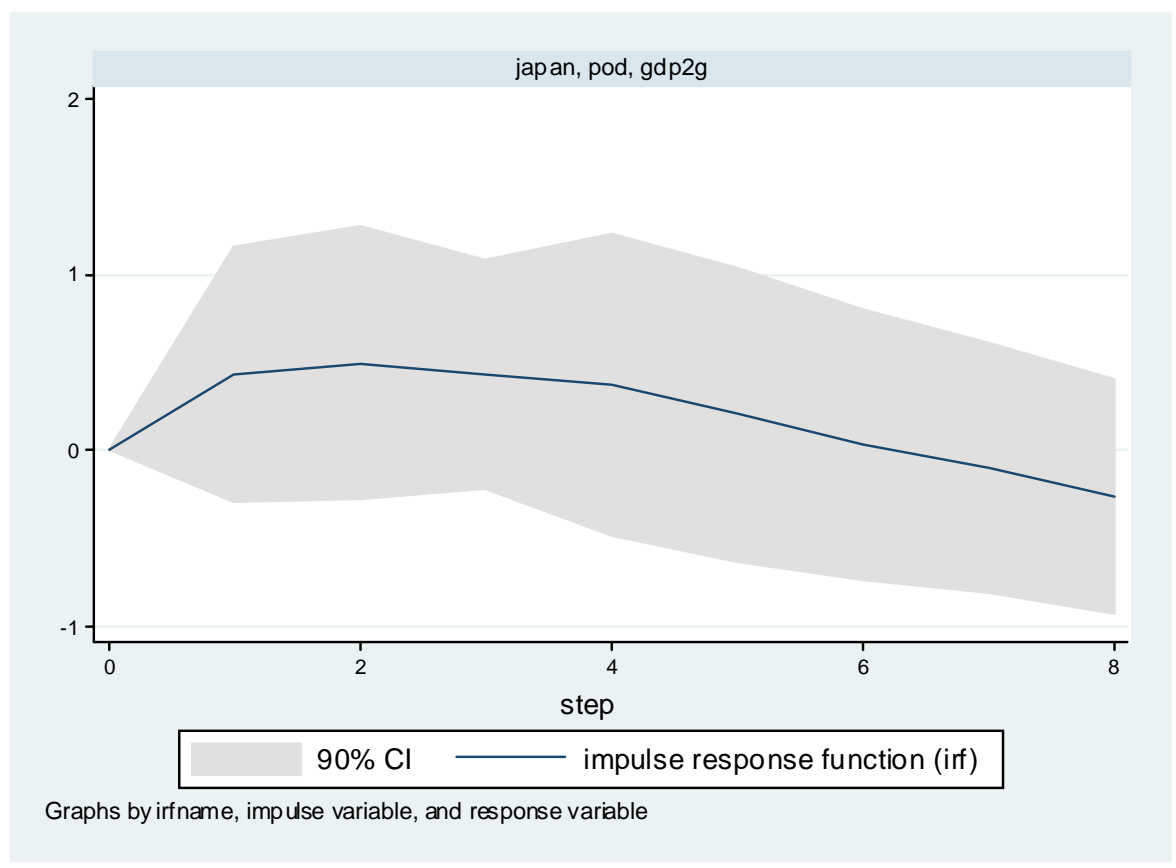

Figure 15: Impulse-response of GDP growth to bank POD (Japan) 


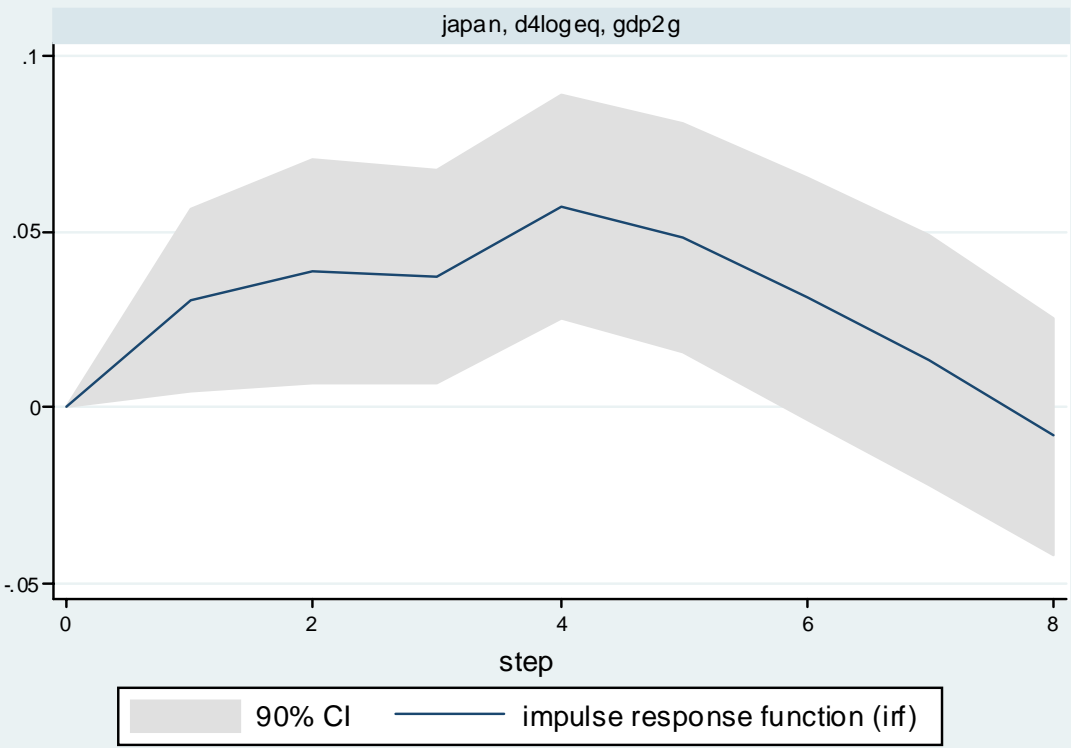

Graphs by irfname, impulse variable, and response variable

Figure 16: Impulse-response of GDP growth to bank equity index (Japan) 


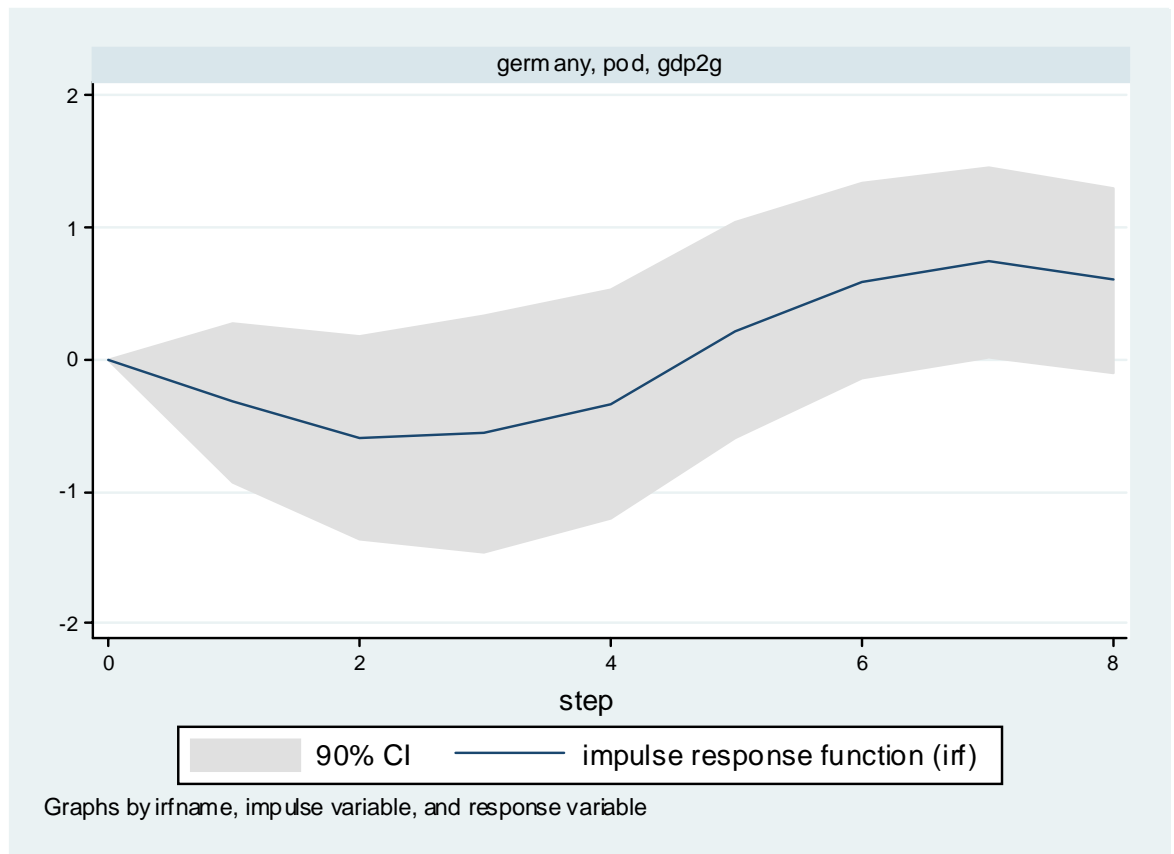

Figure 17: Impulse-response of GDP growth to bank POD (Germany) 


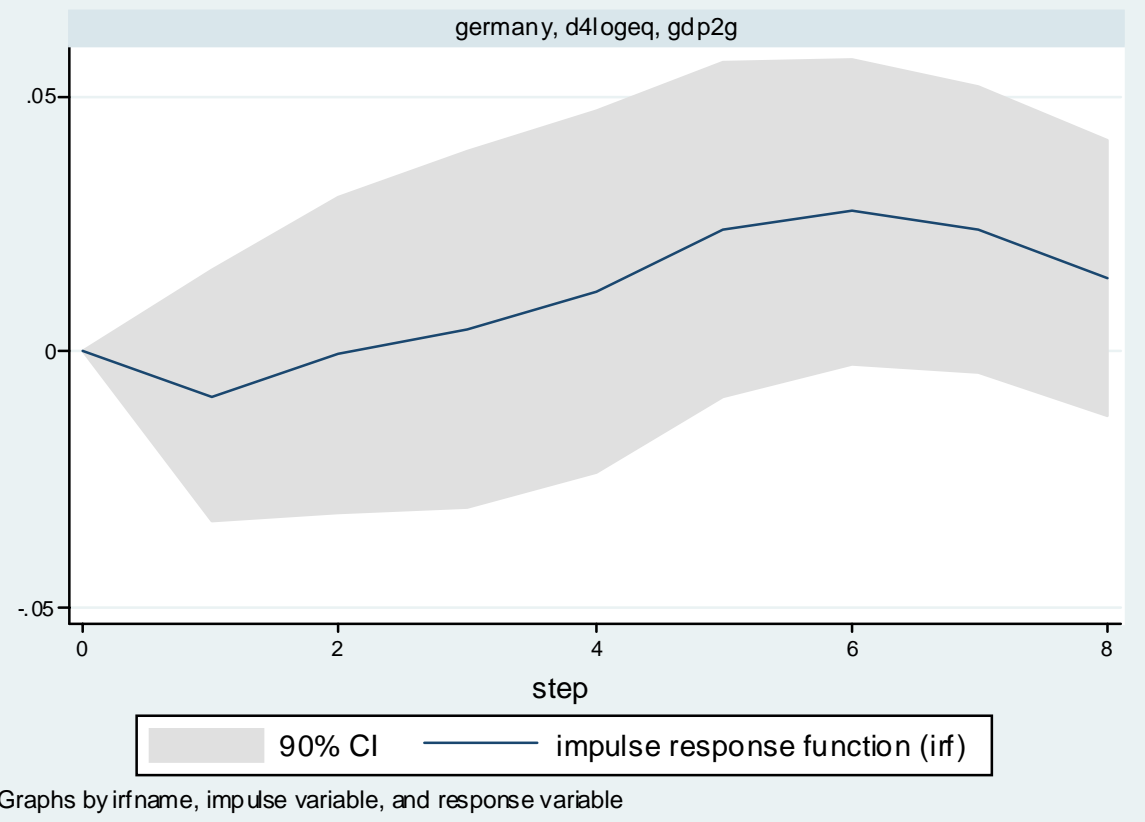

Figure 18: Impulse-response of GDP growth to bank equity index (Germany) 


\section{References}

Allen B., and G.E. Wood (2006), 'Defining and Achieving Financial Stability,' Journal of Financial Stability, forthcoming.

Arellano, M. and O. Bover (1995), 'Another look at the Instrumental Variable Estimation of Error Component Models', Journal of Econometrics, 68, pages 29-51.

Bank for International Settlements (1998), 'Implications of Structural Change for the Nature of Systemic Risk,' Basel, Switzerland.

Bhattacharya, S., Goodhart, C.A.E., Sunirand, P., Tsomocos, D.P. (2003), 'Relative performance, banks and sequential contagion', University of Oxford, mimeo.

Caprio, G., and D. Klingebiel (1996), 'Bank Insolvencies: Cross-Country Experience,' Policy Research Working Paper No 1620, World Bank.

Caprio, G. and D. Klingebiel (2003), 'Episodes of Systemic and Borderline Financial Crises', World Bank, mimeo.

Crockett, A. (1997), 'Maintaining Financial Stability in a Global Economy,' in Federal Reserve Bank of Kansas City's Symposium, Jackson Hole, Wyoming, August 28-30.

Foot, M. (2003) 'Protecting Financial Stability - How good are we at it?,' speech given at the University of Birmingham, June 6. Available on line at http://www.fsa.gov.uk/Pages/Library/

Goodhart, C.A.E. (2004), 'Some new directions for financial stability?', Per Jacobsson lecture, available at http://www.bis.org/events/agm2004/sp040627.pdf.

Goodhart, C.A.E. and B. Hofmann (2005), 'The Phillips Curve, the IS curve and Monetary Transmission: Evidence for the US and the Euro Area', CESifo Economic Studies, Vol. 51, 4/2005, pages 757-75.

Goodhart, C.A.E., B. Hofmann, and M. Segoviano (2005), 'Default, Credit Growth, and Asset Prices,' London School of Economics, mimeo.

Goodhart, C.A.E., P. Sunirand, and D.P. Tsomocos (2004), 'A Model to analyse financial fragility: applications,' Journal of Financial Stability, Vol. 1 (1), pages $1-30$.

Goodhart, C.A.E., P. Sunirand, and D.P. Tsomocos (2005), 'A risk assessment model for Banks,' Annals of Finance, Vol. 1, pages 197-224.

Goodhart, C.A.E., P. Sunirand, and D. P. Tsomocos. (2006 a), 'A Model to Analyse Financial Fragility,' Economic Theory, Vol. 27, pages 107-142.

Goodhart, C.A.E., P. Sunirand, and D.P. Tsomocos (2006 b), 'A Time Series Analysis of Financial Fragility in the UK Banking System,' Annals of Finance, Vol. 2 (1), pages 1-21.

Goodhart, C.A.E. and L. Zicchino (2005), 'A model to analyse financial fragility,' Bank of England Financial Stability Review, June, pages 106-115.

Haldane A., S. Hall, V. Saporta, and M. Tanaka (2004), 'Financial Stability and macroeconomic models', Bank of England Financial Stability Review, June, pages $80-88$.

Hellman T. F., K. C. Murdock, and J. E. Stiglitz (2000), 'Liberalization, Moral Hazard in Banking, and Prudential Regulation: Are Capital Requirements Enough?,' American Economic Review, Vol. 90(1), pages 147-165.

Issing, O. (2003), 'Monetary and Financial Stability: Is There a Trade-off?,' paper presented at the Conference on Monetary Stability and the Business Cycle, BIS, Basel, March 28-29, 2003. 
Kaminsky, G., and C. Reinhart (1999), 'The Twin Crises: The Causes of Banking and Balance-of-Payments Problems,' American Economic Review, Vol. 88, pages $473-500$.

Lindgren, C.J., G. Garcia, and M.I. Saal (1996), Bank Soundness and Macroeconomic Policy, Washington D.C., International Monetary Fund.

Love, I. (2001), 'Estimating Panel-data Autoregressions, Package of Programs for Stata,' Columbia University, mimeo.

Minsky, H. P. (1985), 'The Financial Instability Hypothesis: A Restatement,' in Arestis and Skouras eds., Post Keynesian Economic Theory.

Mishkin F.S. (1994), 'Global Financial Instability: Framework, Events, Issues,' Journal of Economic Perspectives, Vol. 13 (4), pages 3-25.

Nier, E. (2005), "Banking stability and transparency," Journal of Financial Stability, Vol.1 (3), pages 342-54.

Repullo R.(2004), "Capital Requirements, Market Power, and Risk-Taking in Banking," Journal of Financial Intermediation, Vol.13, pages 156-182.

Repullo R., and J. Suarez (2004), "Loan Pricing under Basel Capital Requirements," Journal of Financial Intermediation, Vol. 13, pages 496-521.

Schwartz A.(1986), 'Real and Pseudo Financial Crises,' in Financial Crises and the World Banking System, Ed. F.H. Capie and G.E. Wood, Macmillan, London.

Shubik, M. and Wilson, C. (1977), 'The optimal bankruptcy rule in a trading economy using fiat money', Journal of Economics, Vol. 37, pages 337-54.

Tsomocos, D. P. (2003a), 'Equilibrium Analysis, banking and financial instability,' Journal of Mathematical Economics, 39 (5-6), pages 619-655.

Tsomocos, D. P. (2003b), 'Equilibrium Analysis, banking, contagion and financial fragility,' Bank of England Working Paper No. 175.

Tsomocos, D. P., and L. Zicchino (2005), 'On Modelling Endogenous Default,' Financial Markets Group Discussion Paper No. 548. 